\title{
Palaeoecological and sedimentological characterisation of Middle Miocene sediments from the Hrvatska Kostajnica area (Croatia)
}

\author{
Anita Grizelj ${ }^{1}$, Monika Milošević ${ }^{1}$, Koraljka Bakrač${ }^{1}$, Ines Galović ${ }^{1}$, Tomislav Kurečić ${ }^{1}$, \\ Valentina Hajek-Tadesse ${ }^{1}$, Radovan Avanić ${ }^{1}$, Mirjana Miknićc ${ }^{1}$, Marija Horvat ${ }^{1}$, Ana Čaić Janković ${ }^{1}$ \\ and Mario Matošević ${ }^{2}$
}

${ }^{1}$ HGI-CGS - Croatian Geological Survey, Department of Geology, Sachsova 2, 10000 Zagreb, Croatia; (corresponding author: agrizelj@hgi-cgs.hr)

2 INA - Industrija nafte d.d, Exploration \& Production, Exploration \& Upstream Portfolio Development, Rock \& Fluid Analysis, Lovinčićeva 4, 10 000, Zagreb, Croatia

doi: $10.4154 / g c .2020 .15$

\section{Article history:}

Manuscript received July 29, 2020 Revised manuscript accepted October 05, 2020 Available online October 23, 2020
Keywords: Pannonian Basin System, Hrvatska Kostajnica area, Badenian, Sarmatian, Microfossils, Pelitic sedimentary rocks, Provenance

\begin{abstract}
The Miocene deposits of the Hrvatska Kostajnica (KOS-I) area belong to the south-western marginal part of the Pannonian Basin System (PBS). Investigation of the lithostratigraphical column included: mineralogical, geochemical, sedimentological and integrated palaeontological (calcareous nannofossil, foraminifers, ostracodes, palynomorphs) analyses. Badenian and Sarmatian sediments of this column were deposited in a marine offshore environment with local input of terrigenous material represented by marls and silty marls. Based on palaeontological data, the recorded palaeoclimate was subtropical in the late Badenian changing to a warm temperate climate of the early Sarmatian. Marly sediments predominantly consist of carbonate (calcite and aragonite) and clay minerals, while quartz and plagioclase are less abundant. Most samples contain a small amount of zeolite minerals from the clinoptilolite/heulandite series. Among the clay minerals, smectite and illite/muscovite are the most abundant. Based on provenance analyses we concluded that the Badenian-Sarmatian marls were predominantly formed by the weathering of acidic (Si-rich) source rock derived material from the neighbouring Inner Dinarides.
\end{abstract}

\section{INTRODUCTION}

The studied area is located in the middle part of Croatia (Fig. 1a), in the south-western part of the Pannonian Basin System (PBS) (HORVÁTH \& ROYDEN, 1981; ROYDEN, 1988) and belongs to the North Croatian Basin (NCB) (PAVELIĆ \& KOVAČIĆ, 2018). The investigated litostratigraphical column of Hrvatska Kostajnica (KOS-I) $\left(45.228337^{\circ} \mathrm{N}, 16.559051^{\circ} \mathrm{E}\right)$ represents the main scarp of the landslide located in the Hrvatska Kostajnica area on the eastern slopes of the Kubarnovo brdo hill, north of the Una River and west of the Kostajničica stream.

Soil breakdown and sliding formed $30 \mathrm{~m}$ outcrop of the Badenian-Sarmatian marly deposits on which sedimentological, mineralogical, geochemical and palaeontological investigations were performed. The simplified Basic Geological Map of the SFRY, $1: 100000$, Kostajnica (Fig. 1b) represents the latest complete geological investigation of the area of Hrvatska Kostajnica. According to JOVANOVIĆ \& MAGAŠ (1986a, 1986b), a broader landslide area is composed of Neogene and Quaternary deposits. Badenian deposits conformably overlie early Miocene sediments and disconformably/transgressively cover Eocene sediments and volcanic-sedimentary sequences. The Lower Sarmatian deposits conformably overlie Badenian deposits and contain marls and clayey limestones.

According to recent research, the NCB during the Early Miocene was predominantly characterised by a fresh-water depositional environment. Marine sedimentation began in the Middle Badenian (ĆORIĆ et al., 2009; BRLEK et al., 2016; PAVELIĆ \& KOVAČIĆ, 2018 and MANDIC et al., 2019a) when this basin was connected to the Hrvatsko Zagorje Basin (HZB). The Badenian marine sedimentation was presented by the deposition of marls in the offshore environment (Vejalnica formation) and coarsegrained material in the shoreface depositional environment (Trstenik member and Vrapče formation) (AVANIĆ et al., 2018). During the Sarmatian, reduced salinity occurred, while sediments were represented by shallow-water conglomerates, calcarenites and limestones (the Pećinka member) as well as horizontally laminated pelitic sediments (the Dolje formation) deposited in a deeper marine environment (AVANIĆ et al., 2018; PAVELIĆ \& KOVAČIĆ, 2018 and references therein). Studies of the provenance of the Middle Miocene sedimentary rocks of the SW margin of NCB are deficient. The only reliable data about the provenance of these sedimentary rocks are from areas $\mathrm{N}$ and NE of Hrvatska Kostajnica investigated by KOVAČIĆ et al. (2011) and GRIZELJ et al. (2017). According to these investigations in the area of Medvednica Mt. and the Slavonian Mts., the sources of material for the Middle Miocene clastic sedimentary rocks were located to the south of the investigated area, in the area of the northern Inner Dinarides, while some of the material was also supplied from locally uplifted blocks in the SW part of the PBS.

The aim of this paper is to reconstruct the Badenian/Sarmatian transition in the area of the SW marginal part of the NCB and PBS based on a multiproxy approach: mineralogical, geochemical, sedimentological and integrated palaeontological analyses (calcareous nannofossil, foraminifers, ostracodes, palynomorphs determination) and palaeoecological reconstruction putting the results in the frame of new chronostratigraphic divisions within the Middle Miocene. Furthermore, the aim of the present study is also to make a contribution to the discussion about the evolution, palaeogeography and climate history of the marine succession in the south-western PBS. 

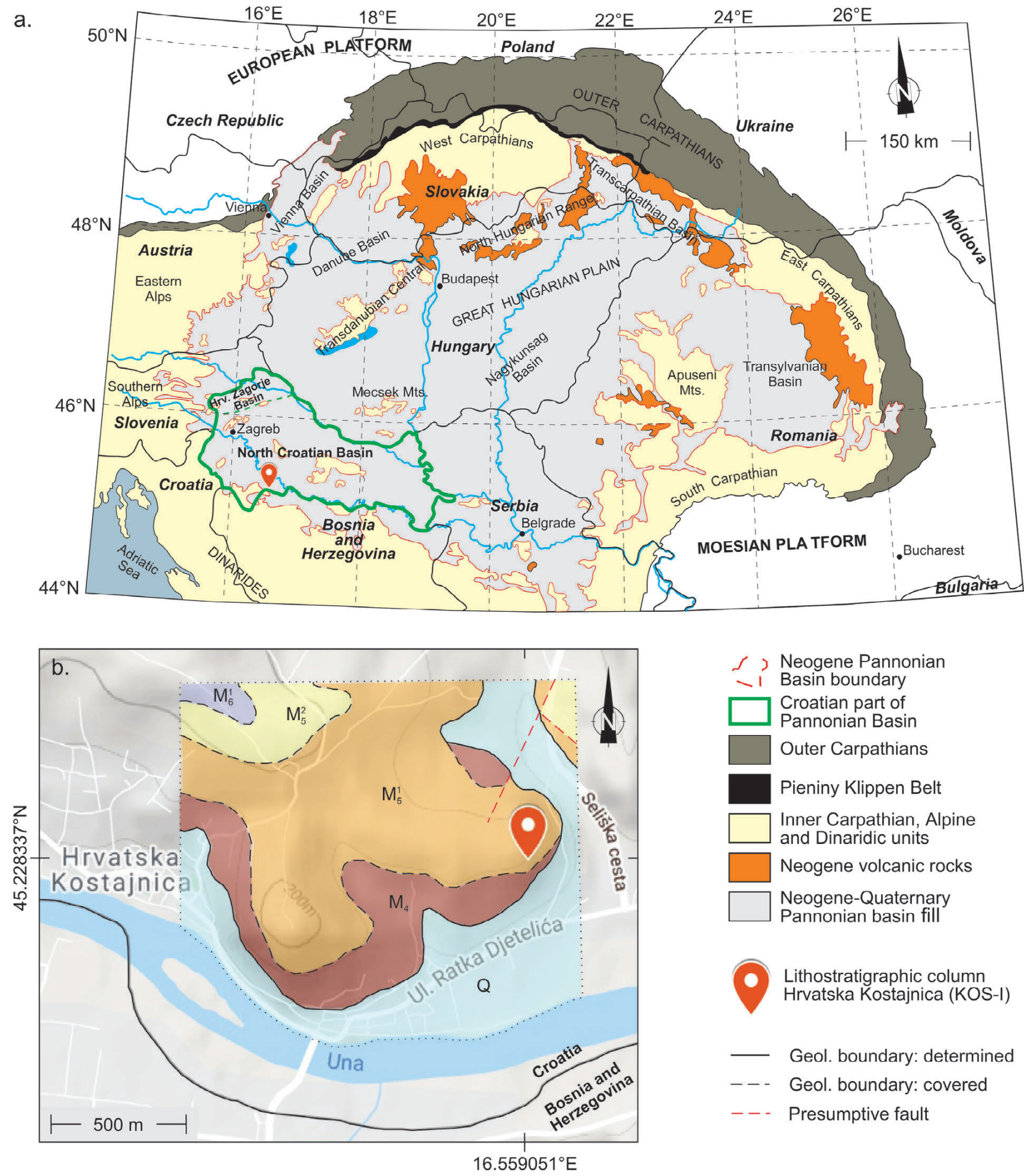

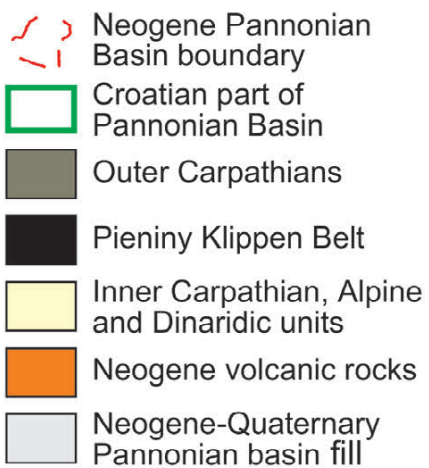

Lithostratigraphic column Hrvatska Kostajnica (KOS-I)

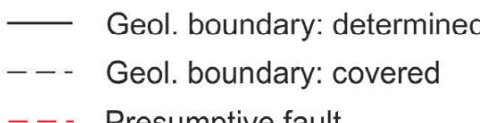

- - Presumptive fault

Figure 1. Geographic and geological settings of the lithostratigraphical column Hrvatska Kostajnica (KOS-I) within the Kubarnovo Brdo landslide: a. Map of the principal tectonic and geographic units of the area of the PBS with an indicated position for the HZB and NCB (simplified after CVETKOVIC et al., 2019). b. Geological map of the Hrvatska Kostajnica area, simplified after the Basic Geological Map of SFRY, 1:100.000, sheet Kostajnica (JOVANOVIC \& MAGAŠ, 1986a) showing the position of the investigated outcrop. Stratigraphic and lithological legend: $\mathbf{M}_{\mathbf{4}}-$ Badenian: Layered marls \& sandstones; $\mathbf{M}_{5}{ }^{1}-$ Sarmatian: Marls \& clayey limestones; $\mathbf{M}_{5}{ }^{2}$ - Sarmatian: Laminated sands with clays \& gravels; $\mathbf{M}_{6}{ }^{1}$ - Pannonian: Clayey limestones; $\mathbf{Q}-$ Quaternary: Alluvial \& slope deposits.

\section{GEOLOGICAL SETTINGS}

The PBS represents one of the Mediterranean back-arc basins, which is surrounded by mountain chains comprising the Alps, Carpathians, and Dinarides. Furthermore, it includes several different-sized, deep depressions (sub-basins) separated by a com- paratively shallow complex of basement rocks (HORVÁTH \& ROYDEN, 1981; ROYDEN, 1988), which influenced the distribution of marine organisms and the development of stress-tolerant species (STEININGER et al., 1988; GALOVIĆ \& YOUNG, 2012). Palaeogeographically, it belongs to the Central Paratethys 
realm, a sedimentation area that, during the Miocene lost and reestablished connections with the Mediterranean and the IndoPacific Ocean on several occasions (HARZHAUSER \& PILER, 2007; KOVÁČ et al., 2017; 2018). Thus, the Early/Late Badenian boundary was marked by a gradual weakening in the connection with the Mediterranean Sea, leading to the interruption of the water exchange between the western and eastern Central Paratethys (KOVÁC $\breve{C}$ et al., 2017). This event is called the Badenian Salinity Crisis (BSC) which began at $13.81 \pm 0.08 \mathrm{Ma}$ (De LEEUW et al., 2010). Moreover, GRADSTEIN et al. (2012) observed a causal relationship between cooling during the glacial event Mi-3b (13.81 Ma) and evaporite formation. Formation of the PBS back-arc basin began in the Early Miocene with continental collision and subduction of the European Plate beneath the Apulian Plate. In the area of North Croatia during the Early Miocene two basins with different depositional histories evolved: the Hrvatsko Zagorje Basin (HZB), which occupied a small area in north-western Croatia, and the North Croatian Basin (NCB), that covered almost the entire area of north Croatia (PAVELIĆ \& KOVAČIĆ, 2018). The syn-rift phase of basin development was characterized by tectonic thinning of the crust and isostatic subsidence, while the post-rift phase was marked by subsidence caused by cooling of the lithosphere (HORVÁTH \& ROYDEN, 1981; ROYDEN et al., 1983; ROYDEN, 1988). In the south-western part of the PBS, the syn-rift phase lasted from the Ottnangian to the Middle Badenian, while the post-rift phase extended from the Late Badenian to the end of the Quaternary (PAVELIĆ \& KOVAČIĆ, 2018).

The oldest deposits of the NCB are Early Miocene fresh-water, alluvial deposits (AVANIĆ et al., 2003; 2018, PAVELIĆ, 2001, PAVELIĆ \& KOVAČIĆ 1999). These deposits were covered by Lower Badenian marls and sandstones deposited in a hydrologically open lake (PAVELIĆ et al., 1998, PAVELIĆ \& KOVAČIĆ, 2018 and references therein). The lacustrine environment was replaced by marine environments with a transitional brackish interval (PAVELIĆ et al., 1998; HAJEK-TADESSE et al., 2009). At the beginning of the Middle Badenian, due to the marine connection, lithothamnium limestones, sandstones and marls intercalated with pyroclastic rocks (caused by occasional volcanic activity) were deposited (AVANIĆ et al., 2003, PAVELIĆ et al., 1998). The Badenian/Sarmatian transition is correlated with the top of polarity Chron C5Ar2n at 12.829 Ma (HOHENEGGER et al., 2014 and references therein). In the Sarmatian, the connections of the PBS with marine areas were significantly reduced which caused changes in depositional environments from marine to marine with reduced salinity and stratification. Sarmatian marls and sandstones were deposited mostly conformable on the Badenian deposits (PAVELIĆ, 2001; PAVELIĆ \& KOVAČIĆ, 2018 and references therein).

\section{METHODS}

\subsection{Fieldwork}

Fieldwork included the following: outcrop rigging and sampling via Single rope technique, in situ determination of sediment type, observation of the type of contacts between intervals, measurement of the dimensions of the sedimentary bodies, sampling for various analyses and finally construction of a lithostratigraphic column.

\subsection{Mineralogical and geochemical analysis}

Mineralogical and geochemical analysis included the following: X-ray powder diffraction (XRPD) analyses (6 samples), chemical analysis of major and trace elements (7 samples) and measurement of $\mathrm{CaCO}_{3}$ using Scheiblers calcimeter (15 samples).

Preparation for XRPD analyses included: sieving the samples through the $63 \mu \mathrm{m}$ sieve, carbonate fraction dissolution by acetic acid with ammonium acetate $\left(1 \mathrm{~mol} \mathrm{dm}^{-3}\right)$ buffer of $\mathrm{pH} 5$ (JACKSON, 1956) and separation of the $<2 \mu \mathrm{m}$ fraction from the insoluble residue of the sample. XRPD patterns were recorded on random mounts of bulk samples, fraction $<63 \mu \mathrm{m}$ and oriented mounts of the $<2 \mu \mathrm{m}$ fraction using the Philips vertical goniometer (type X'Pert) equipped with a Cu-tube (HGI-CGS), and using the following experimental conditions: $45 \mathrm{kV}, 40 \mathrm{~mA}, \mathrm{PW}$ $3018 / 00$ PIXcel detector, primary beam divergence $1 / 4^{\circ}$ and continuous scan ( $\operatorname{step} 0.02^{\circ} 2 \theta / \mathrm{s}$ ). Oriented mounts of the $<2 \mu \mathrm{m}$ fraction were recorded after the following treatments: a) air drying, b) ethylene-glycol solvation, c) heating to $400^{\circ} \mathrm{C}$ and $550^{\circ} \mathrm{C}$. The $\mathrm{X}$-ray interpretation was performed using the HIGH SCORE PLUS (2016) calculation and PDF-4 / MINERALS 4.5 (2020) databases. Quantitative analysis was performed according to SCHULTZ (1964).

Chemical analyses of samples were undertaken by the Bureau Veritas Commodities Canada Ltd., (www.acmelab.com) in Vancouver (Canada). After lithium borate $\left(\mathrm{LiBO}_{2}\right)$ fusion, the major elements content was determined by inductively coupled plasma emission spectroscopy (ICP-ES), while trace elements were measured on an inductively coupled plasma mass spectrometer (ICP-MS).

Provenance analyses were performed following the results of chemical analysis of major and trace elements using oxide or elemental ratios, ternary diagrams and diagrams based on the elemental ratios.

Reconstruction of provenance based on the major elements was performed by $\mathrm{SiO}_{2} / \mathrm{Al}_{2} \mathrm{O}_{3}, \mathrm{~K}_{2} \mathrm{O} / \mathrm{Al}_{2} \mathrm{O}_{3}$ and $\mathrm{Na}_{2} \mathrm{O} / \mathrm{K}_{2} \mathrm{O}$ ratios.

For the analysis of provenance based on trace element content, elemental ratios dependant on provenance including $\mathrm{La} / \mathrm{Co}$, $\mathrm{Th} / \mathrm{Co}, \mathrm{Th} / \mathrm{Sc}, \mathrm{Th} / \mathrm{Cr}, \mathrm{Eu} / \mathrm{Eu}^{*}\left[\mathrm{Eu}^{*}=\mathrm{Tb} \cdot(\mathrm{Sm} / \mathrm{Tb})-2 / 3\right], \mathrm{LREE} /$ HREE and diagrams La-Th-Sc, Th-Sc-Zr/10, Nb/Y $-\mathrm{Zr} / \mathrm{TiO}_{2}$ proposed by BHATIA \& CROOK (1986), CULLERS (1994; 2000) and WINCHESTER \& FLOYD (1977) were used.

The degree of chemical weathering of the source rocks was constrained by calculating the chemical index of alteration (CIA= $\left[\mathrm{Al}_{2} \mathrm{O}_{3} /\left(\mathrm{Al}_{2} \mathrm{O}_{3}+\mathrm{CaO} *+\mathrm{Na}_{2} \mathrm{O}+\mathrm{K}_{2} \mathrm{O}\right)\right] \times 100$ (NESBITT \& YOUNG, 1982). Oxides are expressed in molar proportions and $\mathrm{CaO}^{*}$ is the amount of $\mathrm{CaO}$ in siliciclastic minerals only, i.e. excluding carbonates and apatite. The data for $\mathrm{CaO}^{*}$ have been corrected according to the procedure described by McLENNAN (1993). Because all the analysed samples contained significant amounts of carbonate component, it was assumed that the correction of $\mathrm{CaO}$ is equal to that of $\mathrm{Na}_{2} \mathrm{O}$.

\subsection{Palaeontological analysis}

\subsubsection{Calcareous nannofossil analyses}

The preparation method of SHAMROCK et al. (2015) was followed for TLM (transmitted light microscope) analyses of calcareous nannofossils, while for SEM (scanning electron microscope) analyses, calcareous nannofossils were coated with gold. Slides were examined using an Olympus BH-2 TLM (HGI-CGS) and JEOL JSM-6510 LV SEM (INA - Industrija nafte d.d.). The relative abundance of the calcareous nannoplankton was estimated after randomly counting more than 200 coccoliths along transects at $750 \mathrm{x}$ magnification (using a $60 \mathrm{x}$ objective) according to SCHMIDT (1978). 


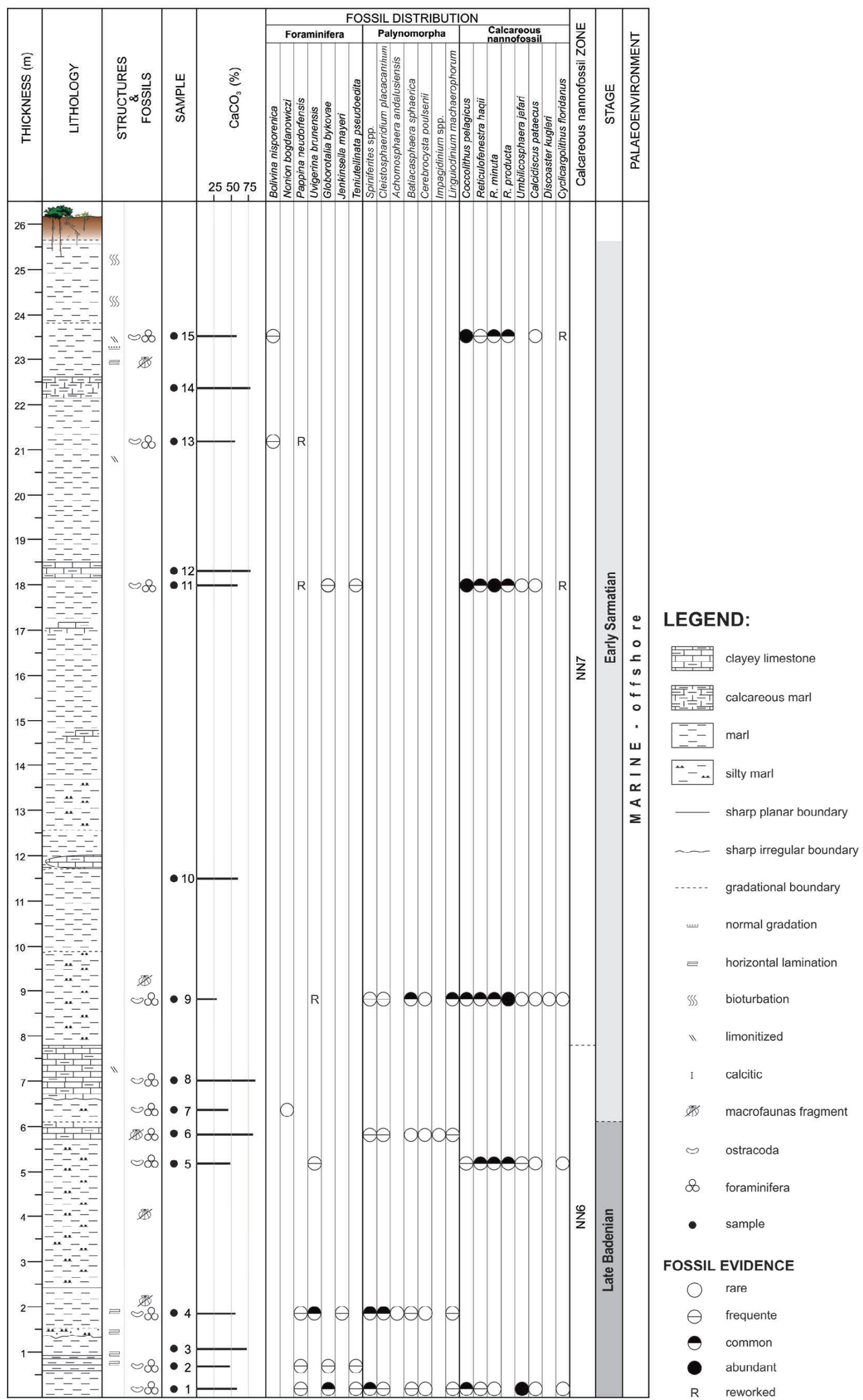

Figure 2. Lithostratigraphic column of the Hrvatska Kostajnica showing sample position, $\mathrm{CaCO}_{3}$ content, fossil distribution and sedimentological history with a palaeoenvironmental interpretation. 


\subsubsection{Palynological analyses}

Palynological analyses were carried out on four samples collected from the lower $10 \mathrm{~m}$ of the column. Standard palynological processing techniques were used to extract the organic matter (e.g. MOORE et al., 1991; WOOD et al., 1996). The samples were treated with sodium pyrophosphate $\left(\mathrm{Na}_{4} \mathrm{P}_{2} \mathrm{O}_{7}\right)$, cold $\mathrm{HCl}(15 \%)$ and $\mathrm{HF}(40 \%)$, to remove carbonates and silica. Heavy liquid $\left(\mathrm{ZnCl}_{2}\right.$, density $\left.>2.1 \mathrm{~kg} / \mathrm{l}\right)$ was used to separate the organic matter from the undissolved inorganic components. The organic residue was sieved through a $10 \mu \mathrm{m}$ mesh. For palynofacies analysis slides were mounted in glycerine and for palynomorphs analysis in silicon oil. Microscopic analyses were performed using an Olympus BH-2 and Leica DM2500 microscopes (HGI-CGS). Photomicrographs were taken using an AmScopeTM camera adapter connected to the AmScope v.3.7 camera software and a Leica MC190 HD camera connected to the Leica LAS EZ software. The palynofacies analyses represent qualitative examinations of the organic matter component groups according to the classifications proposed by TYSON (1995). Samples are plotted in the AOM-phytoclast-palynomorph (APP) ternary diagram to characterize the palaeoenvironment according to TYSON (1995).

\subsection{3.. Foraminiferal and ostracod analyses}

Altogether 12 samples along the column were prepared for ostracod and foraminiferal analyses, both benthic and planktonic species. Approximately $200 \mathrm{~g}$ of sediment per sample was disaggregated by soaking in diluted hydrogen peroxide for $48 \mathrm{~h}$, then washed through sieves $(0.25 ; 0.125 ; 0.09$ and $0.063 \mathrm{~mm})$ and dried at room temperature. All fossil remains (ostracods, foraminifera, bryozoans, gastropods, pteropods, bivalves fragments, otoliths, and fish remains) were hand-picked from each dried residue and observed under a binocular microscope (WILD M3Z) and Zeiss stereomicroscope. All picked specimens were classified and counted but not statistically analyzed.

Planktic and benthic foraminifers are mainly classified based on CICHA et al. (1998); POPESCUE \& CRIHAN (2004; 2005 a,b; 2008; 2011); FILIPESCUE \& SILYE (2008); GEDL et al. (2016); PERYT et al. (2014); SCHÜTZ et al. (2007); DUMITRIU et al. (2017) and TÓTH et al. (2010).

Ostracod species identifications were based on Van MORKHOVEN (1963), HARTMANN \& PURI (1974) and HORNE et al. (2002).

To interpret palaeoenvironmental conditions, calcareous benthic foraminifera are divided into different morphogroups based on their test morphology and mode of coiling. This widely used approach shows the relationship between the test morphology and ecological life preference of modern benthic taxa (SILYE, 2015 and references therein,). Ecological conditions required for each foraminiferal species are mainly accepted from MURRAY (2006) and SILYE (2015) and references therein.

Specimens considered stratigraphically important were documented using the SEM JEOL JSM-35CF system at the HGICGS.

All micropalaeontological samples, organic residues and palynological slides are curated at the Department of Geology, HGI-CGS, Zagreb, Croatia.

\section{RESULTS}

\subsection{Sedimentology}

The Hrvatska Kostajnica (KOS-I) lithostratigraphic column has a total thickness of $25.6 \mathrm{~m}$, which consists of upper Badenian and
Sarmatian pelitic sedimentary rocks (Figs. 1b, 2). Field research and measurement of $\mathrm{CaCO}_{3}$ has shown that the column consists of marls, and clayey limestones, while calcareous marls and silty marls are rare.

Marls contain 48-60\% $\mathrm{CaCO}_{3}$, silty marls $29-49 \% \mathrm{CaCO}_{3}$, calcareous marls $77 \% \mathrm{CaCO}_{3}$ and clayey limestones $81-88 \%$ $\mathrm{CaCO}_{3}$ (Fig. 2). There is visible bedding dipping toward the north (N-NW) at a $10^{\circ}$ angle, although the internal structure in individual layers is rarely visible. Lithological boundaries between the described intervals are mostly sharp and planar or gradational, except at $1.3 \mathrm{~m}$ and $6.6 \mathrm{~m}$ from the base of the outcrop, where the boundary is described as sharp and irregular. Horizontal lamination is present in the lower part of the outcrop and rarely in the upper part. At the top of the outcrop (from 22.6 to $25.6 \mathrm{~m}$ ) there are bioturbation marks. Finally, there is no clearly visible discordance between the lower (Badenian) and upper (Sarmatian) parts of the lithostratigraphical column.

\subsection{Mineralogy and geochemistry}

The mineralogical composition and chemical composition of the marl samples are given in Tab. 1 .

Table 1 shows the results of the quantitative mineral composition of the bulk marl samples and semi-quantitative results of the fraction $<63 \mu \mathrm{m}$ and $<2 \mu \mathrm{m}$ of the insoluble residue obtained by XRPD. The main mineral components are calcite and clay minerals while quartz and aragonite are present in a lesser quantity. In the fraction $<63 \mu \mathrm{m}$ of insoluble residue, besides clay minerals and quartz, all samples contain a small amount of plagioclase. Zeolites from the clinoptilolite/heulandite series are present in a lesser quantity in all samples except sample 15 (Fig. 3 and Tab. 1). Sample 1 contains a small amount of pyrite. In the fraction $<2 \mu \mathrm{m}$ of insoluble residue smectite/I-S and illite/mus-

Table 1. Quantitative mineral composition of bulk samples and the semi-quantitative mineral composition of the $<63 \mu \mathrm{m}$ fraction of insoluble rock residue obtained by XRPD according to the procedure described by SCHULTZ (1964). Clay mineral content was determined from the $<2 \mu \mathrm{m}$ fraction of insoluble rock residue. Qtz - quartz, Cal - calcite, Arg - aragonite, Cli/Hul - clinoptilolite/heulandite, $\mathrm{PI}$ - plagioclase, $\mathrm{Py}$ - pyrite, Sme/l-S - smectite/illite-smectite, III/Ms - illite/muscovite, Vrm - vermiculite, KIn - kaolinite, Chl - chlorite, XXX - dominant $(>50 \%), X X-$ abundant $(20-50 \%), X$ - subordinate $(1-20 \%),+-$ traces $(<1 \%)$.

\begin{tabular}{|c|c|c|c|c|c|c|c|}
\hline \multirow{2}{*}{ SAMPLE } & \multicolumn{7}{|c|}{ KOS-I } \\
\hline & & 1 & 4 & 5 & 9 & 11 & 15 \\
\hline \multirow{4}{*}{$\begin{array}{c}\text { BULK } \\
\text { SAMPLE } \\
\text { (wt. \%) }\end{array}$} & Qtz & 7 & 8 & 11 & 11 & 8 & 7 \\
\hline & Cal & 41 & 38 & 33 & 16 & 59 & 58 \\
\hline & Arg & 18 & 18 & 16 & 13 & & \\
\hline & CLAY & 34 & 36 & 40 & 60 & 31 & 35 \\
\hline \multirow{5}{*}{$<63 \mu \mathrm{m}$} & Qtz & $X X$ & $X X$ & $X X$ & $x$ & $X X$ & $X X$ \\
\hline & CLAY & $X X X$ & $X X X$ & $X X X$ & $X X X$ & $X X X$ & $X X X$ \\
\hline & $\mathrm{Cli} / \mathrm{Hul}$ & + & $X$ & $x$ & $X$ & $x$ & \\
\hline & $\mathrm{PI}$ & $x$ & $x$ & $x$ & $x$ & + & $X$ \\
\hline & Py & $x$ & & & & & \\
\hline \multirow{6}{*}{$<2 \mu \mathrm{m}$} & Sme/l-S & $X X$ & $X X$ & $X X$ & $X X$ & $X X$ & $X X$ \\
\hline & III/Ms & $X X$ & $X X$ & $X X$ & $X X$ & $X X$ & $X X$ \\
\hline & Vrm & + & & & & + & \\
\hline & Kln & $x$ & $x$ & $x$ & $x$ & $x$ & $X$ \\
\hline & Chl & + & + & & + & & \\
\hline & Qtz & + & + & + & + & + & \\
\hline
\end{tabular}



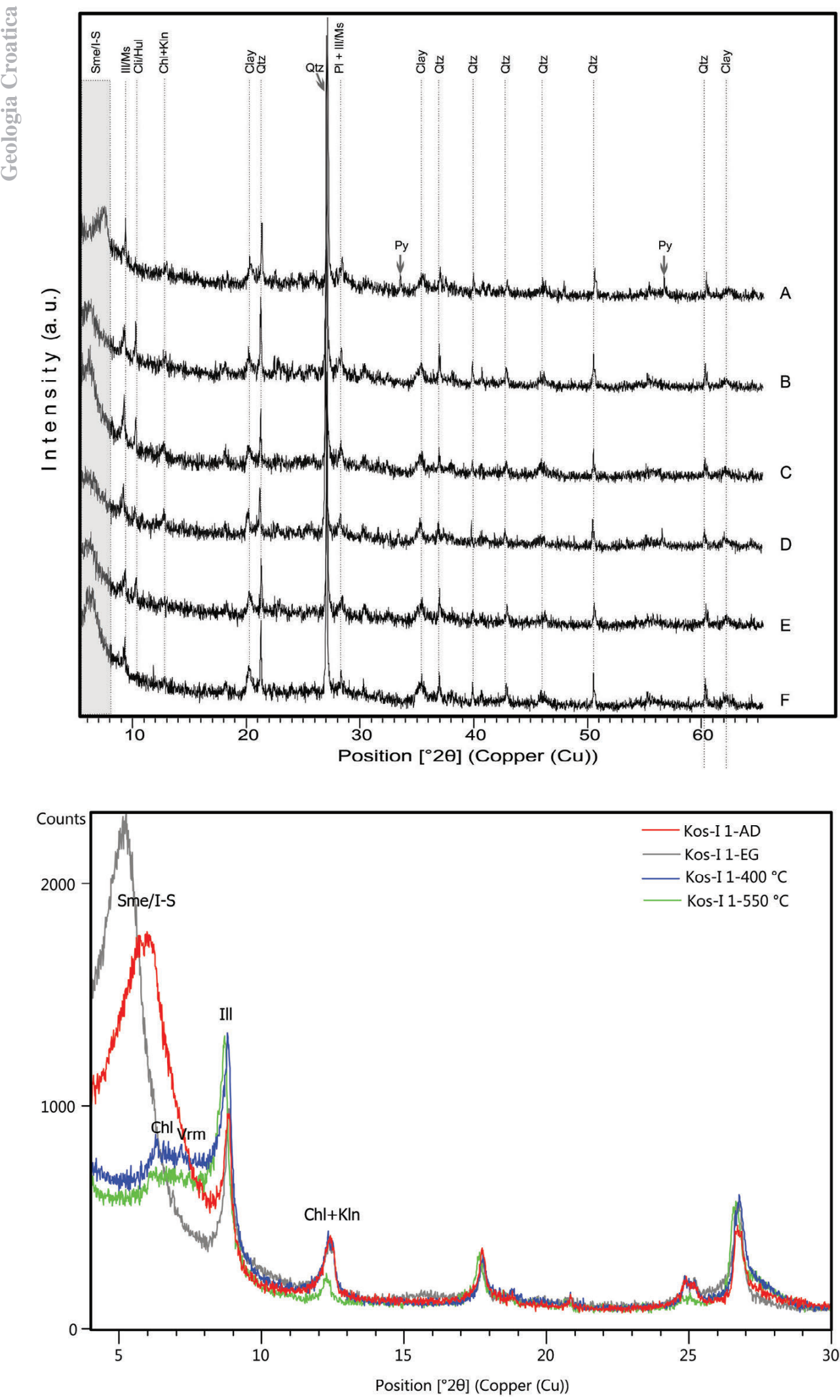

Figure 3. XRD pattern of the $<63 \mu \mathrm{m}$ fraction of the insoluble rock residue. A: KOS-I 1 , B: KOS-I 4, C: KOS-I 5, D: KOS-I 9, E: KOS-I 11, F: KOS-I 15. Abbreviations are the same as in Table 1.
Figure 4. XRD pattern of the $<2 \mu \mathrm{m}$ fraction of insoluble rock residue of sample KOS-I 1 recorded after the following treatments: red line: air-dried sample, grey line: ethylene-glycol treated sample, blue line: sample heated to $400^{\circ} \mathrm{C}$; green line: sample heated to $550^{\circ} \mathrm{C}$. covite are well represented in all samples, while kaolinite is present in all samples in a lesser quantity (Tab. 1 and Fig. 4). Quartz is present in trace amounts in all samples except sample 15. Vermiculite and chlorite were determined in only a few samples (Tab. 1).

In Tab. 2, besides the chemical composition of marl sediments, the major element oxide ratios, trace element ratios, and the CIA index are listed.

\subsection{Micropalaeontology}

\subsubsection{Calcareous nannofossil assemblages}

Among 42 taxa of calcareous nannofossils based on the occurrence frequency, 13 taxa were identified in all samples: Calcidiscus leptoporus, Ca. pataecus, Coccolithus pelagicus, Cyclicargolithus floridanus, Helicosphaera carteri, Pontosphaera longiforaminis, Reticulofenestra haqii, $R$. minuta, R. minutula, 
Table 2. Content of major (wt. \%), trace elements (ppm) and some ratios and CIA weathering index.

\begin{tabular}{|c|c|c|c|c|c|c|c|}
\hline \multirow{2}{*}{ ELEMENTS } & \multicolumn{7}{|c|}{ KOS-I } \\
\hline & 1 & 4 & 5 & 6 & 9 & 11 & 15 \\
\hline $\mathrm{SiO}_{2}$ & 21.41 & 25.08 & 28.79 & 9.44 & 38.43 & 22.73 & 23.66 \\
\hline $\mathrm{Al}_{2} \mathrm{O}_{3}$ & 6.73 & 7.34 & 8.77 & 3.00 & 12.29 & 6.53 & 6.77 \\
\hline $\mathrm{Fe}_{2} \mathrm{O}_{3}$ & 2.40 & 1.31 & 3.12 & 1.42 & 5.17 & 2.58 & 2.29 \\
\hline $\mathrm{MgO}$ & 0.99 & 1.02 & 1.12 & 0.66 & 1.57 & 0.95 & 1.23 \\
\hline $\mathrm{CaO}$ & 34.02 & 32.07 & 27.69 & 45.96 & 17.33 & 33.69 & 32.97 \\
\hline $\mathrm{Na}_{2} \mathrm{O}$ & 0.38 & 0.44 & 0.45 & 0.15 & 0.63 & 0.33 & 0.28 \\
\hline $\mathrm{K}_{2} \mathrm{O}$ & 1.17 & 1.32 & 1.66 & 0.54 & 2.27 & 1.19 & 1.23 \\
\hline $\mathrm{TiO}_{2}$ & 0.33 & 0.39 & 0.45 & 0.15 & 0.70 & 0.33 & 0.36 \\
\hline $\mathrm{P}_{2} \mathrm{O}_{5}$ & 0.15 & 0.13 & 0.22 & 0.06 & 0.08 & 0.21 & 0.23 \\
\hline $\mathrm{MnO}$ & 0.01 & 0.01 & 0.02 & 0.02 & 0.03 & 0.01 & 0.02 \\
\hline $\mathrm{Cr}_{2} \mathrm{O}_{3}$ & 0.01 & 0.02 & 0.02 & 0.01 & 0.02 & 0.01 & 0.01 \\
\hline $\mathrm{Ba}$ & 225.00 & 517.00 & 629.00 & 219.00 & 535.00 & 494.00 & 165.00 \\
\hline $\mathrm{Ni}$ & 91.00 & 54.00 & 72.00 & 38.00 & 102.00 & 65.00 & 57.00 \\
\hline Sc & 7.00 & 8.00 & 9.00 & 4.00 & 13.00 & 7.00 & 7.00 \\
\hline LOI & 32.10 & 30.50 & 27.30 & 38.40 & 21.10 & 31.10 & 30.70 \\
\hline SUM & 99.71 & 99.69 & 99.71 & 99.83 & 99.73 & 99.76 & 99.80 \\
\hline TOT/C & 9.93 & 8.18 & 6.40 & 10.81 & 5.22 & 7.77 & 7.70 \\
\hline TOT/S & 1.18 & 0.12 & 0.04 & $<0,02$ & 2.14 & 0.03 & $<0,02$ \\
\hline V & 172.00 & 183.00 & 189.00 & 72.00 & 206.00 & 150.00 & 161.00 \\
\hline $\mathrm{Cr}$ & 95.79 & 109.48 & 116.32 & 41.05 & 123.16 & 88.95 & 68.42 \\
\hline Co & 5.80 & 3.00 & 7.90 & 1.80 & 13.10 & 2.80 & 3.90 \\
\hline $\mathrm{Ga}$ & 7.30 & 8.00 & 9.90 & 3.00 & 13.60 & 6.30 & 6.60 \\
\hline $\mathrm{Rb}$ & 58.20 & 65.50 & 76.30 & 25.20 & 107.30 & 57.40 & 57.40 \\
\hline $\mathrm{Sr}$ & 1685.00 & 1796.70 & 1570.40 & 983.10 & 1118.60 & 1308.40 & 920.50 \\
\hline$Y$ & 16.90 & 17.90 & 20.00 & 8.20 & 21.40 & 16.40 & 17.50 \\
\hline $\mathrm{Zr}$ & 73.00 & 78.20 & 86.80 & 30.80 & 127.10 & 70.20 & 76.30 \\
\hline $\mathrm{Nb}$ & 5.90 & 7.00 & 7.40 & 2.80 & 11.50 & 5.80 & 6.10 \\
\hline Th & 5.00 & 5.20 & 6.10 & 1.90 & 8.50 & 4.70 & 4.90 \\
\hline Cs & 5.80 & 6.30 & 7.30 & 2.40 & 9.70 & 5.70 & 5.70 \\
\hline $\mathrm{Hf}$ & 2.20 & 2.30 & 2.30 & 0.70 & 3.30 & 1.90 & 2.00 \\
\hline $\mathrm{La}$ & 17.60 & 18.50 & 22.40 & 8.60 & 26.40 & 17.20 & 18.20 \\
\hline $\mathrm{Ce}$ & 32.00 & 32.90 & 41.70 & 13.30 & 50.10 & 30.00 & 32.90 \\
\hline $\operatorname{Pr}$ & 3.92 & 3.92 & 4.93 & 1.66 & 5.79 & 3.57 & 4.00 \\
\hline $\mathrm{Nd}$ & 13.50 & 15.30 & 17.60 & 5.90 & 21.60 & 14.40 & 15.60 \\
\hline $\mathrm{Sm}$ & 2.82 & 2.97 & 3.70 & 1.20 & 4.22 & 2.69 & 3.01 \\
\hline $\mathrm{Eu}$ & 0.63 & 0.66 & 0.75 & 0.28 & 0.80 & 0.59 & 0.65 \\
\hline $\mathrm{Gd}$ & 2.75 & 3.01 & 3.65 & 1.31 & 3.80 & 2.78 & 2.87 \\
\hline $\mathrm{Tb}$ & 0.47 & 0.49 & 0.58 & 0.22 & 0.62 & 0.42 & 0.47 \\
\hline Dy & 2.64 & 2.78 & 3.40 & 1.27 & 3.65 & 2.69 & 3.02 \\
\hline $\mathrm{Ho}$ & 0.62 & 0.60 & 0.75 & 0.30 & 0.75 & 0.56 & 0.56 \\
\hline $\mathrm{Er}$ & 1.70 & 1.76 & 2.21 & 0.87 & 2.29 & 1.62 & 1.73 \\
\hline $\mathrm{Tm}$ & 0.26 & 0.25 & 0.31 & 0.13 & 0.34 & 0.23 & 0.26 \\
\hline $\mathrm{Yb}$ & 1.62 & 1.58 & 1.92 & 0.81 & 2.15 & 1.43 & 1.53 \\
\hline Lu & 0.29 & 0.25 & 0.33 & 0.12 & 0.32 & 0.22 & 0.25 \\
\hline Sn & 2.00 & 2.00 & 2.00 & $<1$ & 3.00 & 1.00 & 2.00 \\
\hline $\mathrm{Ta}$ & 0.50 & 0.50 & 0.40 & 0.20 & 0.60 & 0.40 & 0.40 \\
\hline U & 7.00 & 14.60 & 5.70 & 3.40 & 14.10 & 5.80 & 7.10 \\
\hline $\mathrm{SiO}_{2} / \mathrm{Al}_{2} \mathrm{O}_{3}$ & 3.18 & 3.42 & 3.28 & 3.15 & 3.13 & 3.48 & 3.49 \\
\hline $\mathrm{Al}_{2} \mathrm{O}_{3} / \mathrm{Ti}_{2} \mathrm{O}$ & 20.39 & 18.82 & 19.49 & 20.00 & 17.56 & 19.79 & 18.81 \\
\hline $\mathrm{K}_{2} \mathrm{O} / \mathrm{Al}_{2} \mathrm{O}_{3}$ & 0.17 & 0.18 & 0.19 & 0.18 & 0.18 & 0.18 & 0.18 \\
\hline $\mathrm{Na}_{2} \mathrm{O} / \mathrm{K}_{2} \mathrm{O}$ & 0.20 & 0.33 & 0.27 & 0.28 & 0.28 & 0.28 & 0.23 \\
\hline $\mathrm{La} / \mathrm{Co}$ & 3.03 & 6.17 & 2.84 & 4.78 & 2.02 & 6.14 & 4.67 \\
\hline $\mathrm{Th} / \mathrm{Co}$ & 0.86 & 1.73 & 0.77 & 1.06 & 0.65 & 1.68 & 1.26 \\
\hline $\mathrm{Th} / \mathrm{Sc}$ & 0.71 & 0.65 & 0.68 & 0.48 & 0.65 & 0.67 & 0.70 \\
\hline $\mathrm{La} / \mathrm{Sc}$ & 2.51 & 2.31 & 2.49 & 2.15 & 2.03 & 2.46 & 2.60 \\
\hline $\mathrm{Th} / \mathrm{Cr}$ & 0.05 & 0.05 & 0.05 & 0.05 & 0.07 & 0.05 & 0.07 \\
\hline $\mathrm{Eu} / \mathrm{Eu}^{*}$ & 0.49 & 0.50 & 0.51 & 0.32 & 0.53 & 0.46 & 0.50 \\
\hline LREE/HREE & 6.36 & 6.47 & 6.50 & 5.77 & 7.34 & 6.44 & 6.50 \\
\hline$\sum$ REE & 80.82 & 84.97 & 104.23 & 35.97 & 122.83 & 78.4 & 85.05 \\
\hline $\mathrm{ClA}$ & 72.76 & 71.82 & 72.77 & 73.54 & 73.04 & 73.31 & 75.01 \\
\hline
\end{tabular}

Rhabdosphaera sicca, Sphenolithus abies, Syracosphaera clathratae, Umbilicosphaera rotula. Two main biostratigraphic Zones NN6 and NN7 were identified (MARTINI, 1971) (Fig. 2). Species diversity is highest (36 taxa) in Zone NN7 in sample 9, while up to 32 taxa were determined in Zone NN6 in sample 1. The most equally dominant species in the record (up to $24 \%$ ) are Coccolithus pelagicus and Umbilicosphaera jafari, followed by less abundant Reticulofenestra producta (up to 17\%), R. minuta (up to $16 \%$ ), small Reticulofenestra sp. (up to 14\%) and Reticulofenestra haqii (up to $12 \%$ ). All scattered and rare taxa $(\leq 9 \%)$ are omitted from the results because they did not affect the palaeoecological interpretations. On the other hand, two rare index species (Calcidiscus pataecus and Discoaster kugleri) contributed to the biostratigraphy.

\section{Late Badenian NN6c Subzone (MĂRUNTEANU, 1999; amended by GALOVIĆ, 2019) (0-5.7 m)}

The first occurrence (FO) of Calcidiscus pataecus is characteristic for the late Badenian where it marks Subzone NN6c of Paratethys (MĂRUNŢEANU, 1999).

Umbilicosphaera jafari (up to $24 \%$ ) is the main component in the assemblage with equally abundant (up to $14 \%$ ) small $R e$ ticulofenestra (Reticulofenestra sp., R. minuta, R. producta) and less abundant small Coccolithus pelagicus (up to $12 \%$ ) and $R e$ ticulofenestra haqii (up to 11\%) (Figs. 2, 5).

\section{Early Sarmatian NN6d?-NN7a Subzone (GALOVIĆ, 2019) $(7.8-23.5 \mathrm{~m})$}

The first occurrence (FO) of Discoaster kugleri is characteristic for the early Sarmatian Subzone NN7a of Paratethys (GALOVIĆ, 2019).

Small to medium-sized Coccolithus pelagicus (up to $24 \%$ ) dominates in the assemblage with less abundant small Reticulofenestra producta (up to $17 \%$ ), R. minuta (up to $16 \%$ ) and $R$. haqii (up to 12\%) (Figs. 2, 5).

\subsubsection{Palynology}

All samples contain palynomorphs in various amounts. The preservation degree of the grains is medium to good, i.e. the structure and sculpture of several grains are partially destroyed, making more precise determination impossible.

In the lower part of the column (samples 1 and 4), gymnosperm species (mostly Pinus) prevailed (90\%). The dinocyst assemblage is dominated by chorate gonyaulacoids (Cleistosphaeridium placacanthum (Fig. 5/17), Lingulodinium machaerophorum, Polysphaeridium zoharyi, Spiniferites ramosus (Fig. 5/16), Melitasphaeridium choanophorum (Fig. 5/15), Hystrichokolpoma rigaudiae (Fig. 5/13), Operculodinium centrocarpum, Op. piaseckii, Achomosphaera andalousiensis (Fig. 5/14), Nematosphaeropsis labyrinthus (Fig. 5/18), N. lemniscata, Dapsilidinium sp.? Cordosphaeridium minimum). In addition, proximate gonyaulacoids (Cerebrocysta poulsenii, Batiacasphaera sphaerica) are also present, as well as prasinophyte algae Titthodiscus mecsekensis, and foraminifera linings. The dinocyst assemblage indicate the Cleistosphaeridium placacanthum Zone (Cpl), BAKRAČ et al. (2012), and the Cerebrocysta poulsenii Assemblage Biozone (Cpo), JIMENEZ-MORENO et al. (2006). The palynofacies is dominated by the amorphous group, mainly derived from terrestrially degraded material (roughly 40-45\%), whereas the phytoclast group is the second most dominant (35\%) and the palynomorph group is the least (20-25\%). Pyrite inclusions, resins and charcoal are present. The depositional environ- 


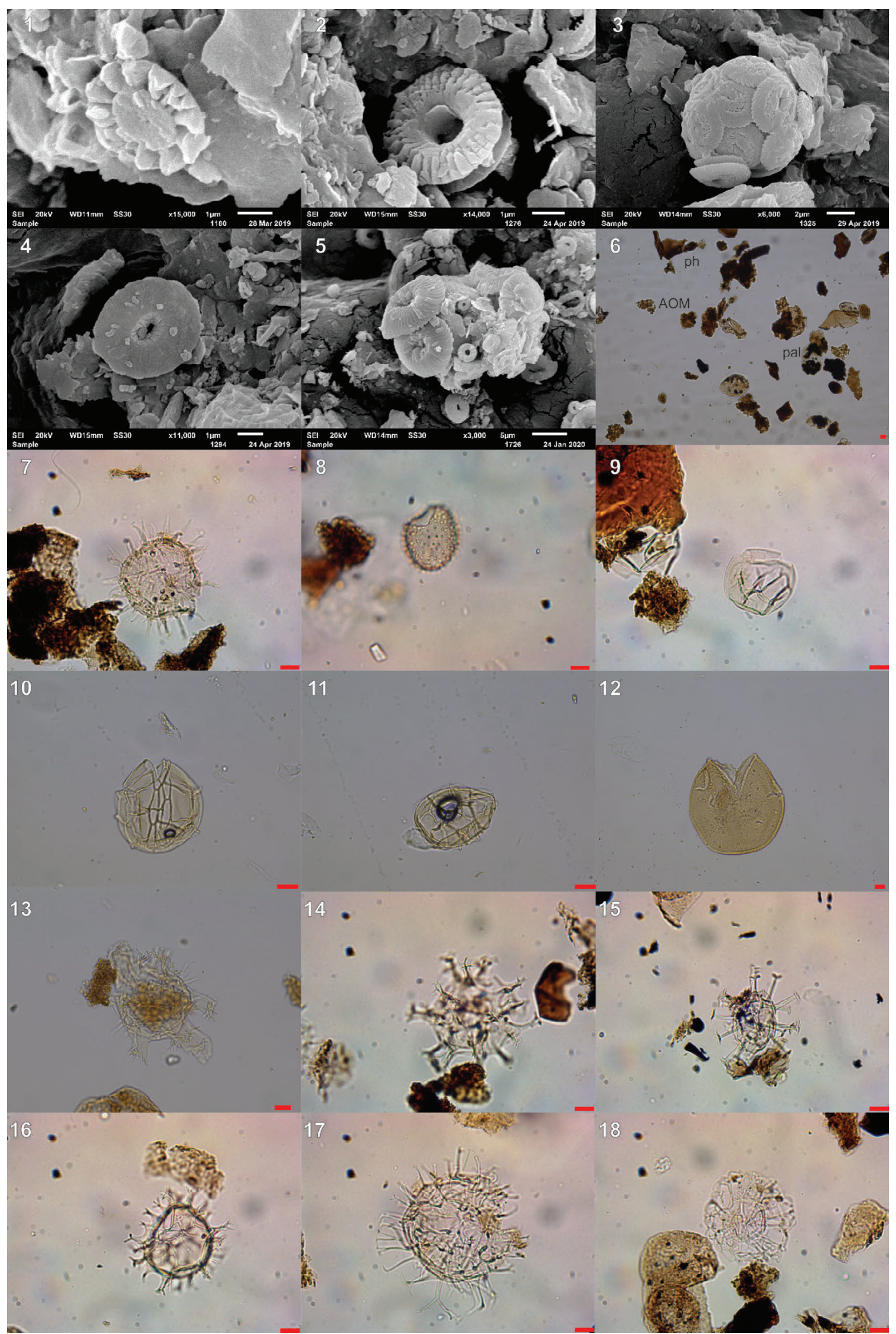

Figure 5. 1. Calcidiscus pataecus (sample 15) Scale bar $=1 \mu ; 2$. Umbilicosphaera jafari (sample 5) Scale bar $=1 \mu ; 3$. small Reticulofenestra species (sample 9) Scale bar $=2 \mu$; 4 . Calcidiscus pataecus (sample 15) Scale bar $=1 \mu$; 5 . Partially disintegrated coccosphaeres of Coccolithus pelagicus (sample 1 ) Scale bar $=5 \mu ; 6$. Palynofacies; pal-palynomorph Pinus with pyrite grains; Ph-phytoclast; AOM- amorphous organic matter (sample 9); 7. Lingulodinium machaerophorum (sample 9), 8. Operculodinium piaseckii (sample 9); 9. Batiacasphaera sphaerica (sample 9); 10. Impagidinium patulum (sample 6); 11. Cerebrocysta poulsenii (sample 6); 12 . Titthodiscus mecsekensis (sample 6); 13. Hystrichokolpoma rigaudiae (sample 4), 14. Achomosphaera andalousiensis (sample 4), 15. Melitasphaeridium choanophorum (sample 1), 16. Spiniferites ramosus (sample 1); 17. Cleistosphaeridium placacanthum (sample 1). 18. Nematosphaeropsis labyrinthus (sample 1) Scale bar $=10 \mu$ for figs. 6-18. 


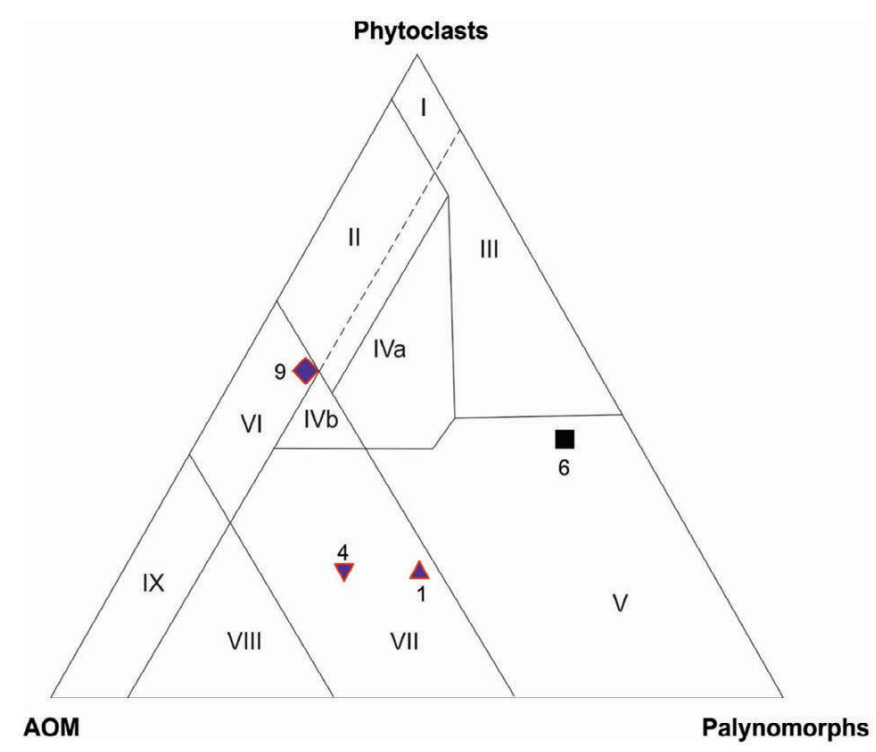

Figure 6. Palynofacies data (AOM-Phytoclast-Palynomorph) presented based on Tyson (1995) diagram. I Highly proximal shelf or basin; II Marginal dysoxicanoxic basin; III Heterolithic oxic shelf (proximal shelf); IV Shelf to basin transition (IVa dysoxic-suboxic; IVb suboxic-anoxic); V Mud-dominated oxic shelf (distal shelf); VI Proximal suboxic-anoxic shelf; VII Distal dysoxic-anoxic shelf; VIII Distal dysoxic-oxic shelf; IX Proximal suboxic-anoxic basin.

ment was a distal dysoxic-anoxic shelf according to the palynofacies (Fig. 6).

On land, zonal vegetation developed, represented by a warmtemperate mixed mesophytic forest, with a large contribution from extrazonal elements (mountain conifer-rich forest). Above the horizon there is one thin layer (sample 6). Dinocysts prevail (60\%), mostly chorate gonyaulacoids (Spiniferites spp., Cleistosphaeridium placacanthum, Lingulodinium machaerophorum, Operculodinium piaseckii). In addition, proximate gonyaulacoids (Cerebrocysta poulsenii, Fig. 5/11, Impagidinium patulum, Fig. 5/10) are also present, as well as chlorophyte algae Botryococcus braunii, prasinophyte algae Crassosphaera sp., and Titthodiscus mecsekensis (Fig. 5/12). The assemblage indicates the Cleistosphaeridium placacanthum Zone (Cpl), BAKRAČ et al. (2012) and Cerebrocysta poulsenii Assemblage Biozone (Cpo) JIMENEZ-MORENO et al. (2006). The amount of the organic residue is very low in proportion and barely enough to allow palynofacies analysis. It is dominated by the palynomorph group (50\%), whereas the phytoclast group was the second most dominant (40\%). The amorphous group account for only ca. $10 \%$ of the organic particles. Some phytoclasts are gelified. Pyrite inclusions and charcoal are present. This palynofacies suggests that deposition took place in a mud-dominated oxic shelf environment (Fig. 6).

In the middle part of the column (sample 9), the dinocyst proportion is somewhat higher than gymnosperm pollen (mostly Pinus). The dinocyst assemblage is dominated by chorate gonyaulacoids (Spiniferites spp., Cleistosphaeridium placacanthum, Lingulodinium machaerophorum (Fig. 5/7), Polysphaeridium zoharyi, Operculodinium piaseckii (Fig. 5/8), Melitasphaeridium choanophorum, Labyrinthodinium truncatum). In addition, proximate gonyaulacoids (Cerebrocysta poulsenii, Batiacasphaera sphaerica (Fig. 5/9) are also common, as well as prasinophyte algae Titthodiscus mecsekensis, Crassosphaera sp., Mecsekia spinosa and foraminifera linings. The terrestrial palynolfora is represented only by elements characteristic for extrazonal vegetation such as montane conifer-rich forests. This assemblage is assigned to the Polysphaeridium zoharyi - Lingulodinium machaerophorum Zone (Pzo-Lma) BAKRAČ et al. (2012) and the Cleistosphaeridium placacanthum Assemblage Biozone $(\mathrm{Cpl})$ JIMENEZ-MORENO et al. (2006). The palynofacies (Fig. 5/6) is dominated by the phytoclast group (50\%), whereas the amorphous group attains $40 \%$ of the particles, while the palynomorph group is the least abundant (10\%) element. Some phytoclast particles are gelified. Pyrite inclusions and charcoal are present. According to the palynofacies from sample 9, the depositional environment was a proximal suboxic-anoxic shelf (Fig. 6).

Alongside the zonal vegetation (warm-temperate mixed mesophytic forest at a very low ratio), extrazonal mountain coniferrich forests were developed.

\subsubsection{Foraminifera}

The distribution of foraminifera from the marl samples is given in Supplement Tab. 1 and Fig. 7.

Altogether, 81 benthic and 31 planktonic species of foraminifera are determined in the lithostratigraphic KOS-I column. Large amounts of reworked Badenian microfossils within the Sarmatian sediments, together with the rare occurrence of Sarmatian index fossils, is the main characteristic of the KOS-I column.

Planktonic species are mostly represented by specimens of the genus Globigerina, Globigerinoides, together with Orbulina species, Globoturborotalita sp., and Turborotalita quinqueloba, with rare occurrences of Velapertina indigena, Paragloborotalia siakensis, and Globigerinita glutinata.

Benthic foraminifera are predominantly represented by calcareous species, miliolids are scarce, while agglutinated species are absent. An engaging feature of the benthic foraminiferal assemblage is the slightly higher occurrence of unicameral foraminifera. Favulina hexagona, Porosolenia tibiscens, Fissurina severantoni, Palliolatella sp. are species determined in the lower part of the column (samples 1 - 4). A high amount of bolivinids and buliminids is determined the KOS-I column as a whole. Benthic species have ranges varying from the early Badenian (e.g. Planularia moravica, Lenticulina cf. clypeiformis, Bolivina fastigia, Amphimorphina hauerina) to the late Badenian (Uvigerina brunnensis, Pappina neudorfensis) which, together with the scarce occurrence of Sarmatian index species (Nonion bogdanowiczi) point to a high rate of reworking along the column. The Sarmatian index fossil is identified in the upper part of the column (above sample 7). The lower part of the column due to the co-occurrence of Bolivina dilatata, Bulimina elongata longa, Uvigerina brunnensis, U. semiornata together with Globigerina bulloides, G. praebulloides, G concinna, and Globigerinoides trilobus is attributed to the late Badenian (DUMITRIU et al., 2017).

Furthermore, index fossils including Nonion bogdanowiczi, Bolivina sagittula, B. nisporenica, B. pseudoplicata, B. moravica, B. moldavica granensis, Fursenkoina sarmatica, Elphidium perscitum, E. ex gr. puscharovski, E. macellum tumidocamerale, E. incertum, E. excavatum, Elphidiella artifex, and Nonion tumidulus point to the Sarmatian age.

Benthic foraminiferal taxa, based on their test morphology and mode of coiling, were clustered into six morphogroups. Morphogroup M1 is composed of forms with a rounded planispiral test (Elphidiella, Nonion, non-keeled elphidiids). They are present throughout the whole KOS-I column. We presume that species from this group belong to the autochthonous assemblage. Morphogroup M2 includes elphidiids (Elphidium crispum, E. 


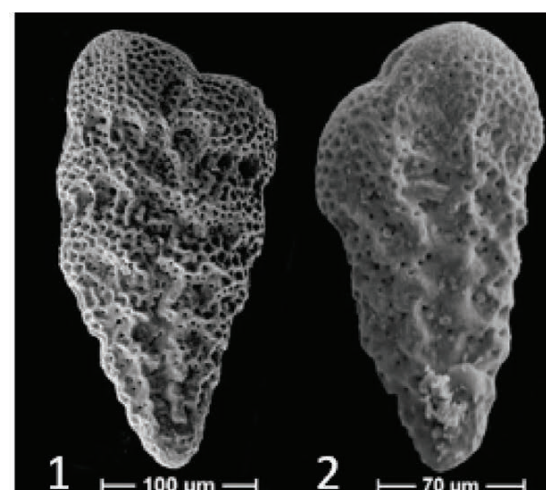

$1 \longmapsto 100 \mu \mathrm{m} \longrightarrow$
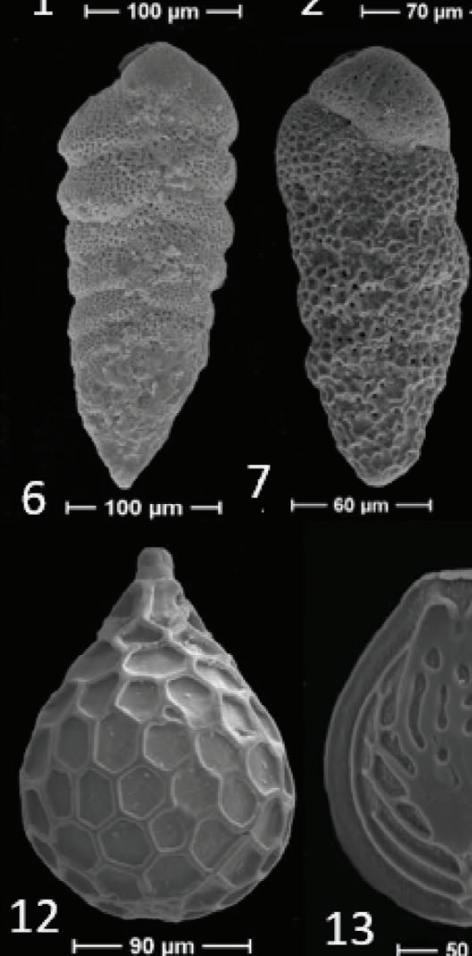

13
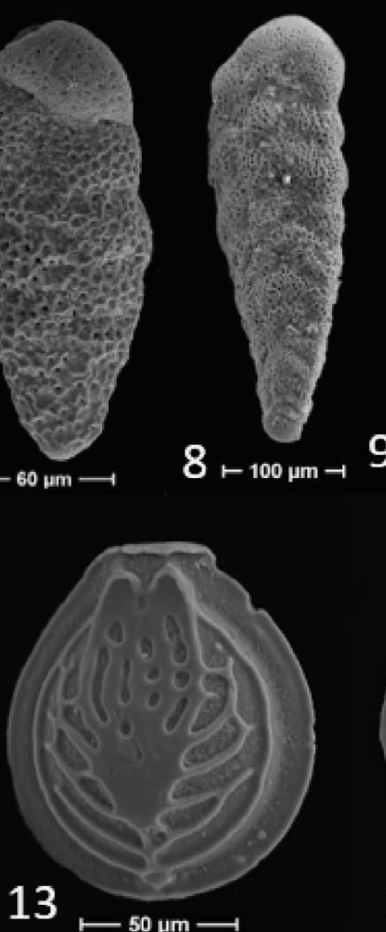

9

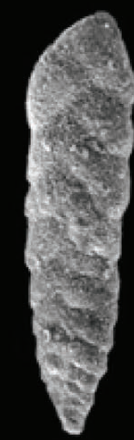

4
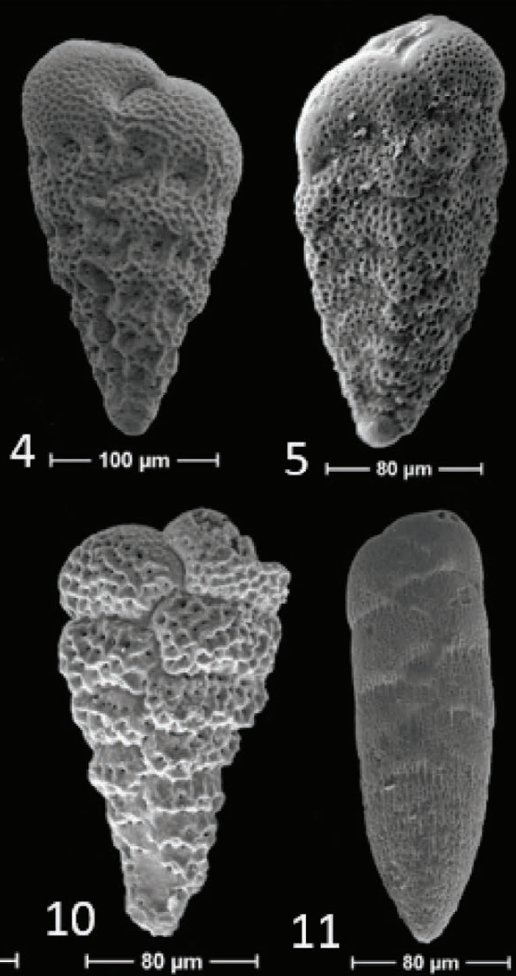

11
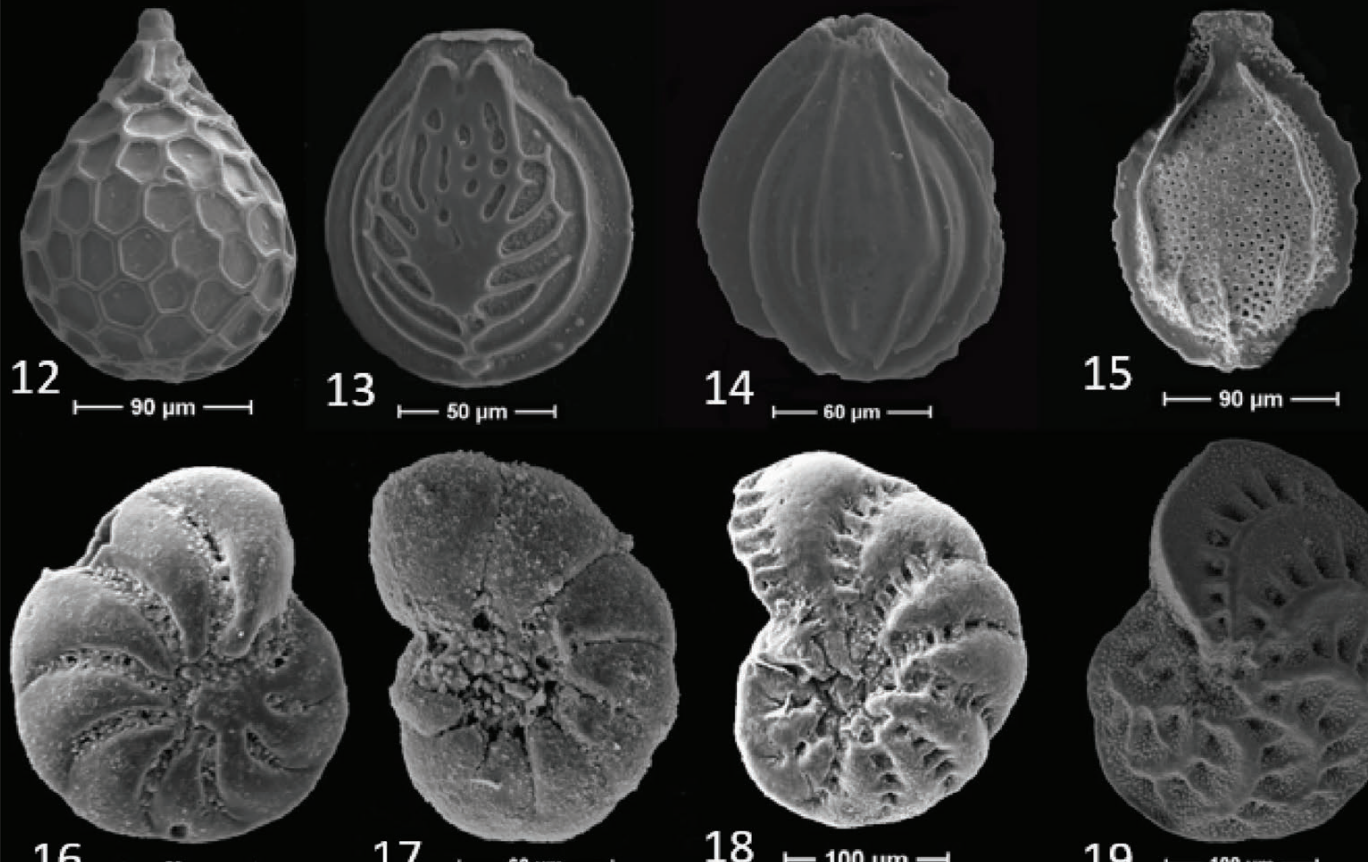

16
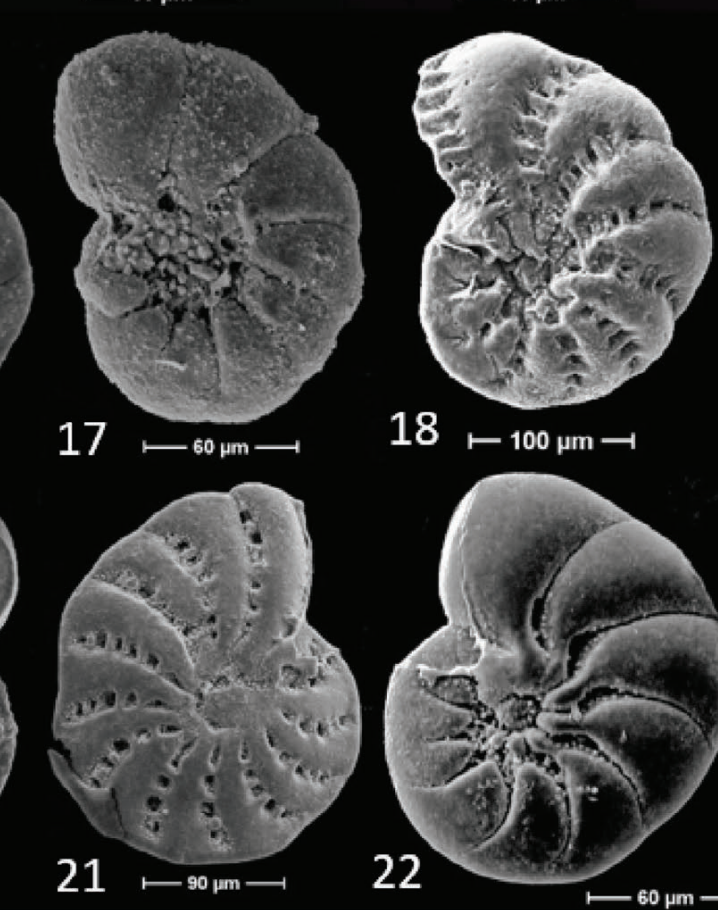

18
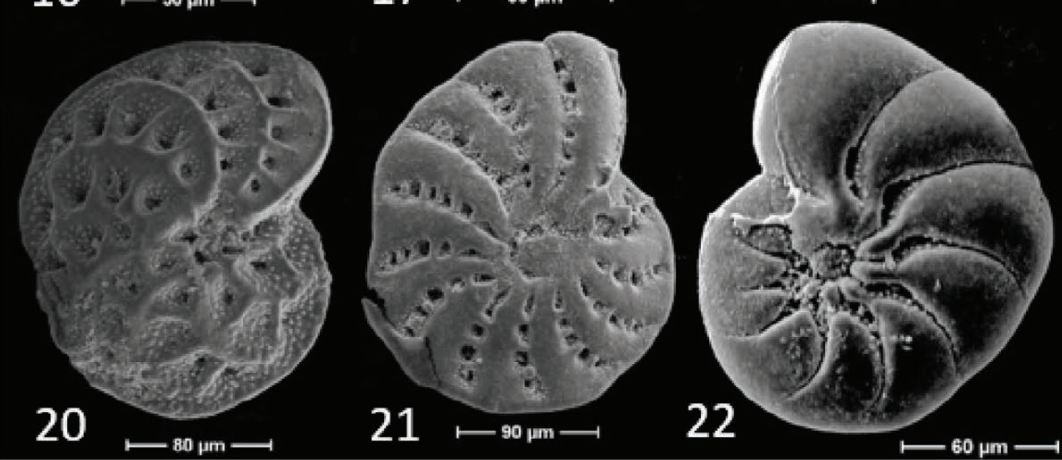

Figure 7. SEM photomicrographs of selected foraminifers from the KOS-I succession. 1. Bolivina plicatella; 2. Bolivina plicatella mera; 3. Bolivina pseudoplicata; 4. Bolivina moldavica; 5. Bolivina moldavica granensis; 6. Bolivina nisporenica; 7. Bolivina moravica; 8. Bolivina papulata; 9 . Bolivina sagittula; 10. Bolivina sarmatica; 11. Bolivina striatulla; 12. Favulina hexagona; 13. Fissurina severantoni; 14. Cursina porocostata; 15. Porosolenia tibiscens; 16. Nonion biporus; 17. Porosononion martkobi; 18. Elphidium excavatum; 19. Elphidium perscitum; 20. Elphidium ex gr puscharovski; 21. Elphidium reussi; 22. Elphidiella artifex; 23. Elphidiella vignaeuxi. 
macellum) of the shallow-shelf environment. Morphogroup M3 is composed of the low trochospiral tests of Ammonia. In the KOS-I column, Ammonia species are more frequent in sample 7. Morphogroup M4 is composed of unilocular lagenids. This morphogroup characterizes the outer shelf to bathyal environments, suboxic marine environments with a low-moderate organic influx (SILYE, 2015 and references therein). In the KOS-I column, they only appear in the lower part. Morphogroup M5 is composed of two genera, Bolivina and Bulimina. Morphogroup M6 represents low-trochospiral rotalids, Cibicidoides and Lobatula species. In samples from the KOS-I column morphogroups with an infaunal mode of life prevail, while the epifaunal lifestyle is subordinate.

\subsubsection{Ostracods}

A total of 10 samples were used for ostracod analyses, taken successively from the KOS-I column. Twenty four ostracod taxa belonging to 15 genera were identified, of which eight species remained in open nomenclature. Distributions of ostracod species are summarised in Supplement Tab. 2, listed alphabetically. Some of the species are illustrated in Fig. 8.

The ostracod fauna within the KOS-I succession includes marine ostracod species that represent six families: Callistocythere cf. postvallata, Callistocythere canaliculata, Cnestocythere sp., Cnestocythere truncata within Cytheridae; Aurila cf. notata, Aurila cf. merita, Aurila sp., Bosquetina carinella, Tenedocythere slebrosa, Tenedocythere sp., Tenedocythere sulcatopunctata within the Hemicytheridae; Amnicythere ? sp. within the Leptocytheridae; Buntonia sp., Costa sp., Olimfalunia ? plicatula, Grinioneis haidingeri within the Trachyleberididae; Paracytheridea triquetra, Semicytherura filicata, Semicytherura cf. alata within Cytheruridae; Loxoconcha sp., Loxocorniculum hastatum, Loxocorniculum cf. schmidi within the Loxoconchi- dae; and Xestoleberis glaberscens and Xestoleberis sp. within the Xestoleberidae.

Ostracods were discovered in small numbers in nine samples, and their species richness was low. Ostracods were absent in sample 6. Common species in samples from the KOS-I column are: Aurila sp. (8 records), Callistocythere cf. postvallata (6 records) and Xestoleberis glaberscens (4 records). The diversity varies throughout the column and is generally low. The maximum number of species (11) was reported in sample 11. Sample 4 contain 10 species. Other samples include relatively low numbers of species: samples 2 and 13; 7 species each, and samples 1 and 5 with 6 species each. In other samples, the number of species varies between 3 and 4, and one sample contains only 2 species.

\subsubsection{Other microfossils}

Rare bryozoans, probably Crisia sp. and Tubulipora sp. (samples 9 and 11), according to FILIPESCU et al. (2014), prefer unstable, shallow and high energy environments. They usually belong to pioneer assemblages.

Pteropods, probably Limacina valvatina, are recognized in samples 4 to 9 . Their occurrence is documented from the early to late Badenian and even in the lower Sarmatian (BOŠNJAK et al., 2017 and references therein). According to BOHN-HAVAS \& ZORN (2002), the species was widely distributed during the Badenian.

\section{DISCUSSION}

\subsection{Sedimentology}

The lithostratigraphic column in Fig. 2 shows continuous sedimentation from the late Badenian to the early Sarmatian. Such a situation is well known from the area of the NCB, where Sarmatian sediments overlie upper Badenian sediments in a continuous depositional succession (VRSALJKO et al., 2006; PAVELIĆ \&

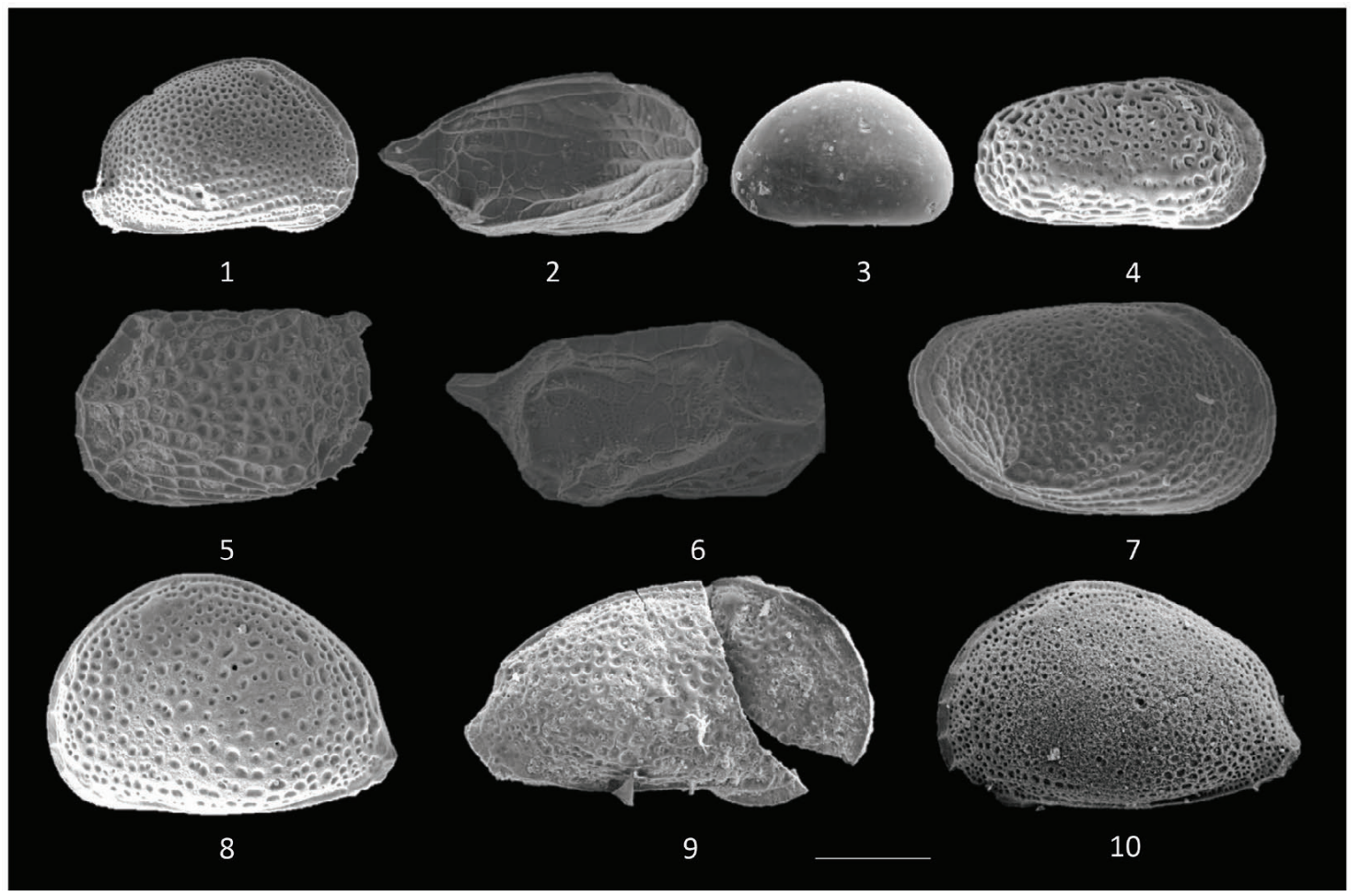

Figure 8. SEM photomicrographs of selected ostracods from the KOS-I succession. 1. Aurila cf. notata, RV external view; 2 . Semycytherura cf. alata, RV external view; 3. Xestoleberis sp., RV external view; 4. Aminocythere ? sp., RV external view; 5. Loxocorniculum cf. schmidi, LV external view; 6. Semicytherura filicata, RV external view; 7. Loxocorniculum hastatum, RV external view; 8. 10. Aurila sp., LV external view; 9. Aurila cf. merita, RV, external view. Scale bars: 100 ㅆm. 
KOVAČIĆ, 2018). Structureless marls, that are represented in most of the lithostratigraphic profile (Fig. 2), suggest sedimentation of fine-grained siliciclastic material from suspension in an open marine environment. Similar conditions recorded on the NE part of Mt. Medvednica indicate sedimentation in the deeper part of the basin which was not significantly affected by the sea-level fall at the end of the Badenian (VRSALJKO et al., 2006). The analysed samples contain calcite and in a lesser quantity aragonite. Carbonates were predominantly deposited from seawater (discussed in section 4.2.). The small amount of carbonate content in the marls could be associated with carbonate detritus derived from fossil skeletons and bioerosion of older carbonate bedrock. The fragments of bryozoans, gastropods, pteropods, bivalves, otoliths, and fish remains, together with marine ostracods, foraminifera, calcareous nanofossils, and palynomorphs indicate a marine depositional environment. The absence of wave action indicators and the presence of palaeontological species from deeper marine environments suggests that sediments were deposited on the shelf or below the base of the wave action (offshore). In contrast, the Badenian/Sarmatian boundary is discontinuous in many cases within Central Paratethys (VRSALJKO et al., 2006; MANDIC et al., 2019b; MANDIC et al., 2019c). This discontinuity is the result of the sea-level fall during the latest Badenian, and the formation of archipelagoes which were affected by erosion resulting in the deposition of shallow-water sediments and reworked Badenian flora and fauna (PAVELIĆ \& KOVAČIĆ, 2018).

Figure 9. shows the stratigraphic position of the KOS-I column correlated with the Ugljevik (MANDIC et al., 2019c) and Donje Orešje columns (VRSALJKO et al., 2006; GALOVIĆ, 2003). The depositional environment of KOS-I column is similar to the environment of the Donje Orešje. Nevertheless, during the Sarmatian deposition occured in the Donje Orešje in a lagoon, while in the studied area it continues in the deeper sea. The Badenian/Sarmatian boundary at the Ugljevik column (Bosnia and Herzegovina) as in many other parts of PBS, is marked by a weakly expressed erosive omission and hiatus (MANDIC et al., 2019c). According to AVANIĆ et al. (2003), these differences were probably the result of local tectonics in the earliest post-rift phase that has a significant role controlling sedimentation in these part of the PBS.

\subsection{Mineralogical composition of marls}

The bulk analyses of marls show that the main mineral components are calcite and clay minerals, while quartz and aragonite are present in lesser quantities. The amount of aragonite is probably of biogenic and/or chemical origin. It is well known that the type of carbonate and its morphology depends on the temperature of the water in which it is generated, together with the concentration of $\mathrm{Ca}^{2+}$ and $\mathrm{Mg}^{2+}$ ions in the solution, salinity and pressure of $\mathrm{CO}_{2}$ (RAO, 1996). Calcite may form when the $\mathrm{Mg} / \mathrm{Ca}$ ratio is $<2$, while aragonite occurs when the $\mathrm{Mg} / \mathrm{Ca}$ ratio is between 2 and 12 (MÜLLER et al., 1972). Moreover, calcite may occur in different environments, while aragonite is usually formed in warm $\left(20-30{ }^{\circ} \mathrm{C}\right)$, shallow marine environments by direct precipitation from seawater, or it forms skeletons of various organisms (LIPPMANN, 1973; RAO, 1996; CHANG et al., 1998, TIŠLJAR, 2001). Such marine and marine environments with reduced salinity existed during both the Badennian and the Sarmatian. Also, part of the aragonite, that is unstable in the subsurface and at standard temperature and pressure, could be altered to the more stable isomorph calcite. In the fraction $<63 \mu \mathrm{m}$ of insoluble residue, besides clay minerals and quartz, all samples contain a small amount of plagioclase and zeolites from the clinoptilolite/heulandite series. Zeolites are present in almost all samples, indicating that they were probably transported from some local source of origin. Such a local source could be the upper Cretaceous deposits in the locality of Volinja near KOS-I column, in which MARKOVIĆ (2002) mentions the occurrence of zeolite minerals. The results of previous provenance studies suggest also that the neighbouring Inner Dinarides produced a significant amount of clastic detritus during the Middle Miocene (KOVAČIĆ

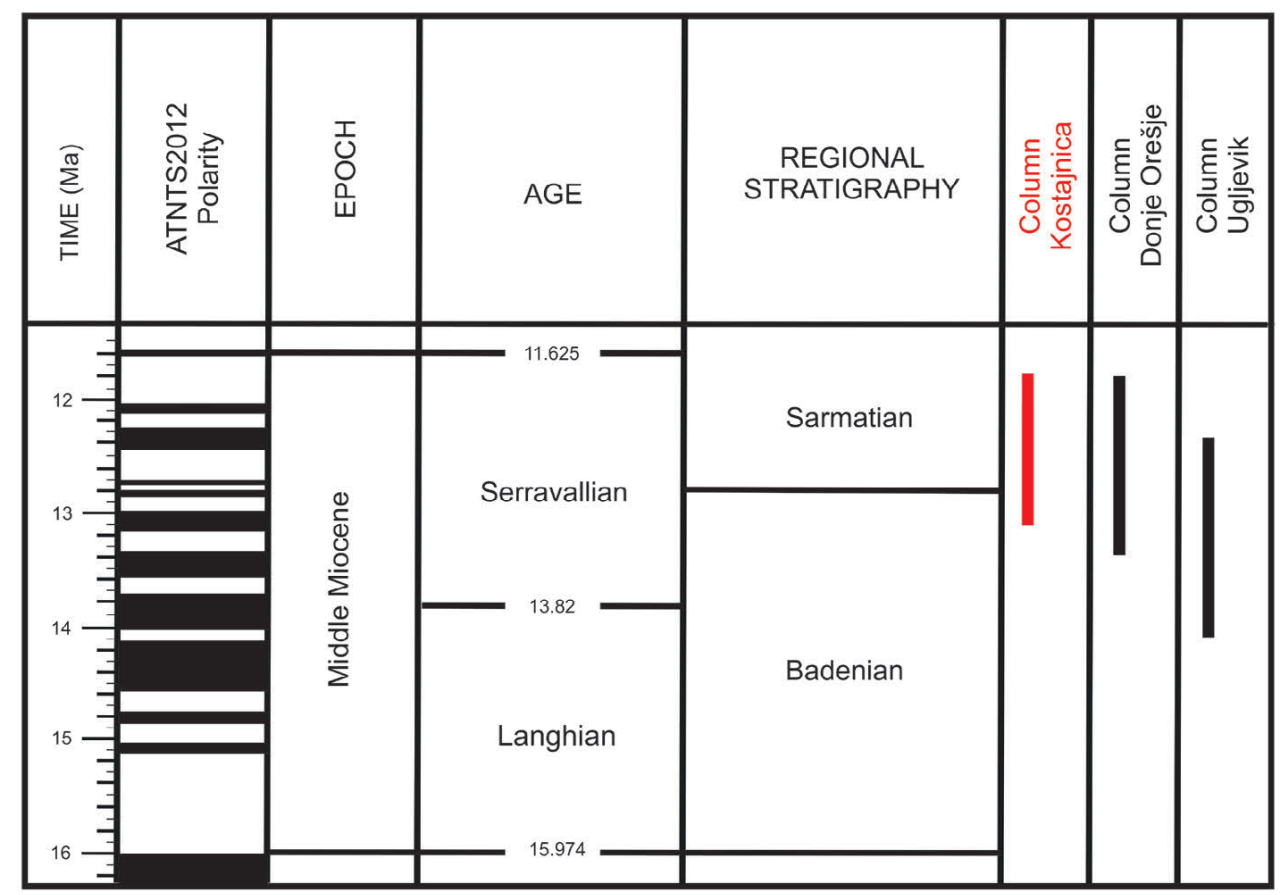

Figure 9. Illustration showing the stratigraphic position of the investigated Hrvatska Kostajnica column (KOS-I) and its correlation with the Ugljevik (MANDIC et al., 2019c) and Donje Orešje columns (GALOVIĆ, 2003; VRSALJKO et al., 2006). Magnetostratigraphy is from HILGEN et al. (2012). The geological time scale is from GRADSTEIN et al. (2012) and HOHENEGGER et al. (2014). 
et al., 2011, GRIZELJ et al., 2017). In the $<2 \mu \mathrm{m}$ fraction of insoluble residue, the main components are smectite/I-S and illite/ muscovite, while kaolinite is present in a lesser amount. In some samples, chlorite and vermiculite are also present. While illite/ muscovite and chlorite are considered typical terrigenous mineral species, formed directly from disintegrating intrusive and metamorphic rocks, kaolinite and vermiculite are characteristic products of chemical weathering (CHAMLEY, 1989). It should also be noted that chlorite is poorly resistant to chemical weathering, which probably explains its presence in small amounts in the analysed marls. According to WEAVER (1989), most smectite occurs as interlayer I-S. Smectites may form from the alteration of volcanic rocks in subaerial and submarine environments and do not suffer from marine and river transportation, and are often carried in the marine environment farther than other minerals because of their high buoyancy (CHAMLEY, 1989). In the investigated profile there were no traces of volcanic activity in the sediment. The occurrence of smectite could be explained by re-deposition from volcanic material from older formations such as tuffs that were determined in the area of Banovina (MANDIC et al., 2012 and MARKOVIĆ, 2017) or alteration of volcanic material which was transported over long distances. Intensive volcanic activity was reported for the Middle Miocene in the wider area of the PBS (PAMIĆ et al., 1995; KOVÁČ et al., 2007; MANDIC et al., 2012; MARKOVIĆ, 2017; BRLEK et al., 2020).

\subsection{Chemical composition and provenance of terrigenous material}

\subsubsection{Major elements}

Variation in the chemical composition of major elements of the samples may be explained by the observed variation in the mineralogy of the samples. $\mathrm{Al}_{2} \mathrm{O}_{3}$ values range between 3.00-12.29 wt \%, an amount related to clay minerals, zeolites and plagioclase. The amount of $\mathrm{Al}_{2} \mathrm{O}_{3}$ and other major elements is dictated to by the amount of $\mathrm{CaO}$, which is mainly related to the amount of calcite and/or aragonite in the samples. This is illustrated in Fig. 4, which shows good positive correlations of $\mathrm{SiO}_{2}, \mathrm{Fe}_{2} \mathrm{O}_{3}, \mathrm{MgO}, \mathrm{Na}_{2} \mathrm{O}$, $\mathrm{K}_{2} \mathrm{O}$ and $\mathrm{TiO}_{2}$ with $\mathrm{Al}_{2} \mathrm{O}_{3}$, while $\mathrm{CaO}$ is strongly negatively cor-
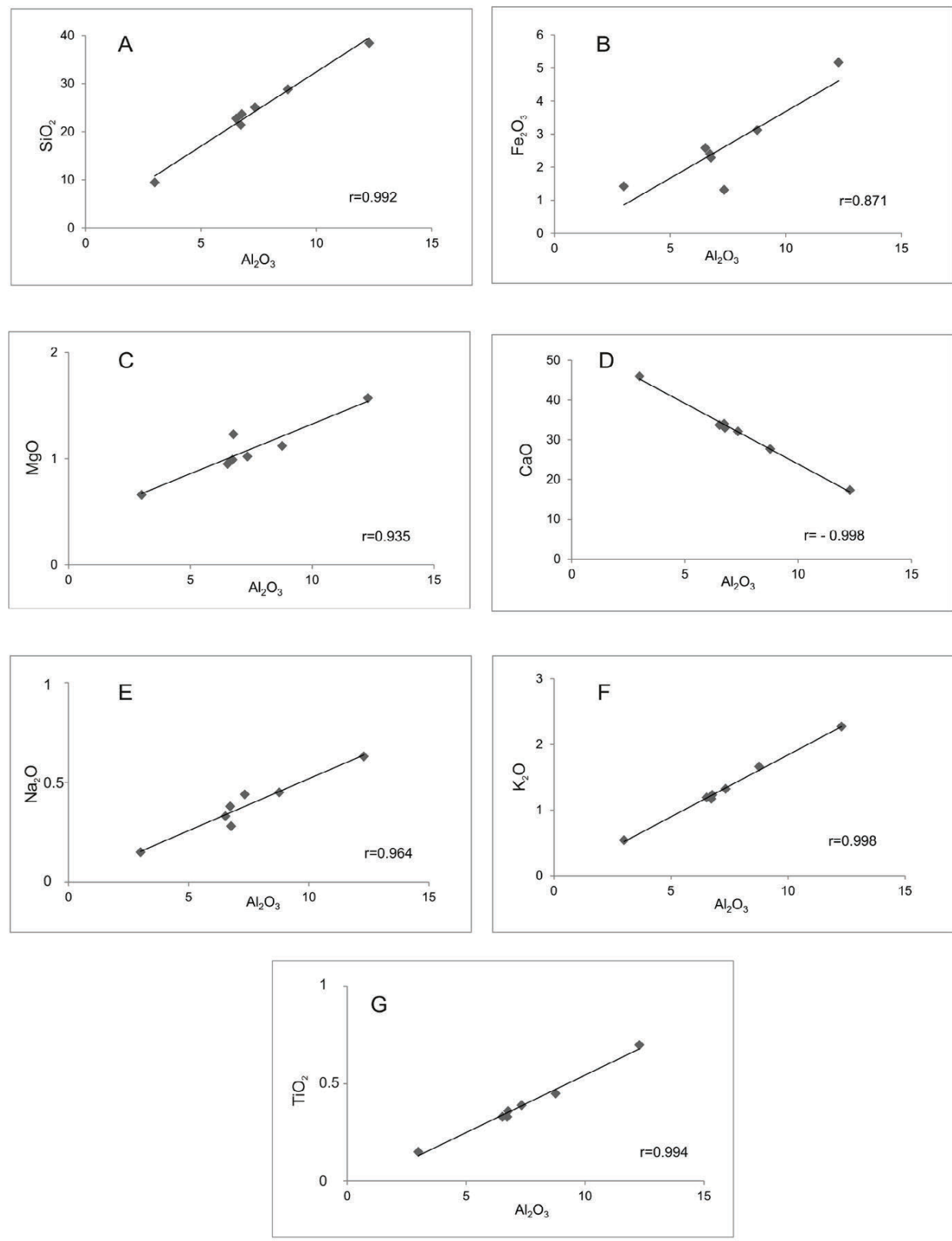
related. Except for clay minerals, zeolites and plagioclase, a certain amount of $\mathrm{SiO}_{2}$ is also associated with the amount of quartz (Tab. 1).

The $\mathrm{SiO}_{2} / \mathrm{Al}_{2} \mathrm{O}_{3}$ ratio proposed by CULLERS (2000) was used as an indicator of the maturity of the clastic sedimentary rocks, as well as for the presence of quartz in relation to the clay minerals and feldspar. This ratio in all samples ranges from 3-3.5 (Tab. 2), and is lower than the values characteristic for the Upper Continental Crust (TAYLOR \& McLENNAN, 1985).

The $\mathrm{Al}_{2} \mathrm{O}_{3} / \mathrm{TiO}_{2}$ ratio in clastic sedimentary rocks is used to distinguish the types of source rocks (GARCIA et al., 1994; ANDERSSON et al., 2004). This ratio $<14$ is indicative of mafic source rocks, whereas a ratio ranging from 19-28 is characteristic for felsic source rocks. The $\mathrm{Al}_{2} \mathrm{O}_{3} / \mathrm{TiO}_{2}$ ratio in the Badennian-Sarmatian marls of KOS-I column ranges from 17.56 to 20.39 (Tab. 2), suggesting that these sediments are derived from felsic source rocks.

The $\mathrm{K}_{2} \mathrm{O} / \mathrm{Al}_{2} \mathrm{O}_{3}$ ratio is used as an indicator of the source composition of pelitic sedimentary rocks and is significantly different for clay minerals and feldspars. The $\mathrm{K}_{2} \mathrm{O} / \mathrm{Al}_{2} \mathrm{O}_{3}$ ratio ranging from $0-0.3$ is indicative of clay minerals, and for feldspars, it ranges from 0.3-0.9 (COX et al., 1995). A $\mathrm{K}_{2} \mathrm{O} / \mathrm{Al}_{2} \mathrm{O}_{3}$ ratio of sediments $>0.5$ indicates a significant content of alkali feldspar relative to other minerals in the source rocks, while a $\mathrm{K}_{2} \mathrm{O} / \mathrm{Al}_{2} \mathrm{O}_{3}$ ratio $<0.4$ suggests recycling of pelitic sedimentary rocks (COX et al., 1995). In the analysed samples, this ratio is less than 0.2 (Tab. 2) suggesting, therefore, they could have been derived from older pelitic sedimentary rocks. From the mineral composition of the analysed marls, it could be presumed that the potassium content in the samples originates from the presence of illite/muscovite. Such a conclusion is supported by the perfect correlation of $\mathrm{K}_{2} \mathrm{O}$ and $\mathrm{Al}_{2} \mathrm{O}_{3}$ (Figure 10f) and the mineral composition of the samples (Tab. 1).

The $\mathrm{Na}_{2} \mathrm{O} / \mathrm{K}_{2} \mathrm{O}$ ratio ranges from $0.20-0.33$ in the analysed samples. Sodium in marls has been associated mainly with plagioclase, and in lesser amounts it could be related to the exchangeable interlayer cations of clay minerals. $\mathrm{Na}_{2} \mathrm{O}$ has a perfect correlation with $\mathrm{Al}_{2} \mathrm{O}_{3}$ in the analysed samples (Fig. 10e).

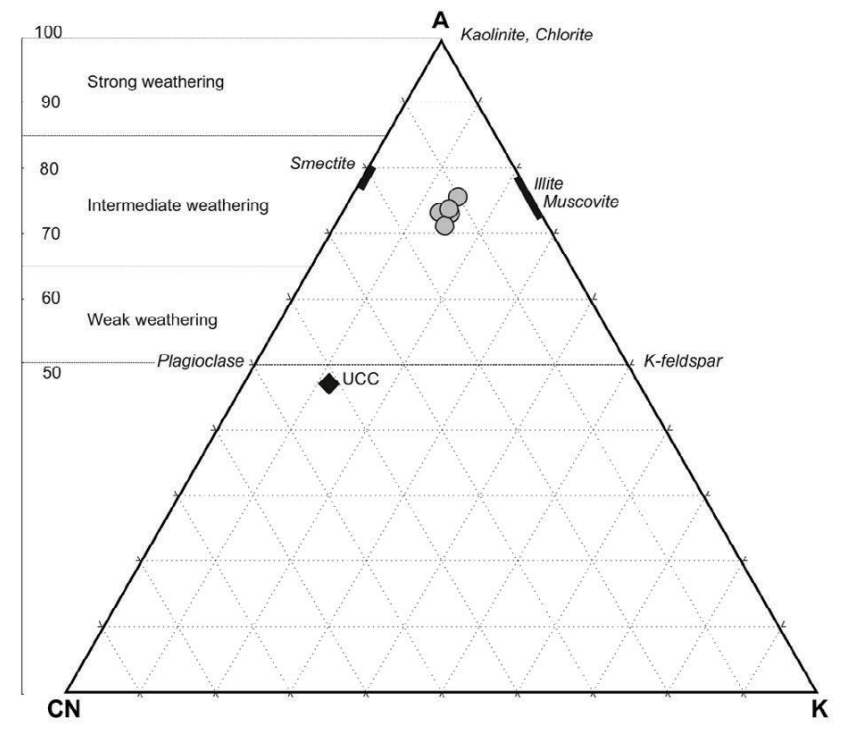

Figure 11. $\mathrm{Al}_{2} \mathrm{O}_{3}-\left(\mathrm{CaO}+\mathrm{Na}_{2} \mathrm{O}\right)-\mathrm{K}_{2} \mathrm{O}$ plot of marl samples of $\mathrm{KOS}-\mathrm{I}$ column (after NESBITT \& YOUNG 1982; 1984) in comparison to the data for Upper Continental Crust (UCC) given by TAYLOR \& MCLENNAN (1985) and the idealized mineral compositions of plagioclase, K-feldspar, kaolinite, chlorite, muscovite, illite and smectite (from NESBITT \& YOUNG, 1984).

The degree of chemical weathering of the source rocks can be constrained by calculating the chemical index of alteration (CIA) proposed by NESBITT \& YOUNG (1982). According to NESBITT \& YOUNG (1982), the CIA values for average shale range from $70-75$, and for clay minerals, illite and montmorillonites from 75.00-85.00. For the analysed marls, the CIA values range from 71.81-75.01 (Tab. 2), and are higher than the UCC values ( $<50$; TAYLOR \& McLENNAN, 1985). The intensity of weathering of the source rock was also deduced by the triangular $\mathrm{Al}_{2} \mathrm{O}_{3}-\left(\mathrm{CaO}+\mathrm{Na}_{2} \mathrm{O}\right)-\mathrm{K}_{2} \mathrm{O}$ plot (after NESBITT \& YOUNG 1982; 1984) with the values of the Upper Continental Crust given by TAYLOR \& McLENNAN (1985), and the idealized compositions of plagioclase, K-feldspar, illite/muscovite, smectite and kaolinite/chlorite (NESBITT \& YOUNG, 1984) (Fig. 11).
Figure 12. Rare earth element plots of marl samples from the KOS-I column normalized to chondrite after TAYLOR \& MCLENNAN (1985).

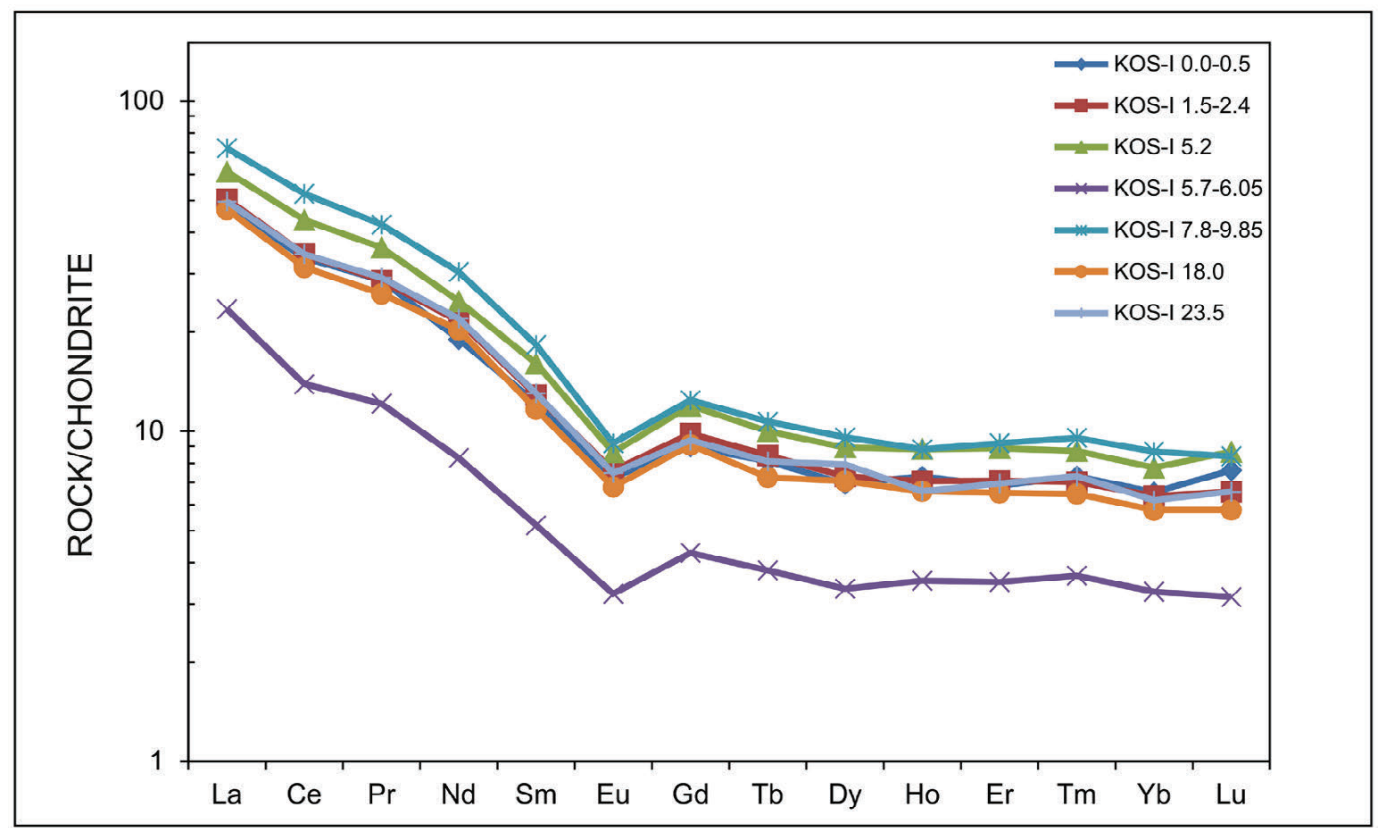


Figure 13. $\mathrm{Nb} / \mathrm{Y}$ vs. $\mathrm{Zr} / \mathrm{TiO}_{2}$ discrimination diagram after WINCHESTER \& FLOYD (1977) for marl samples of the KOS-I column.

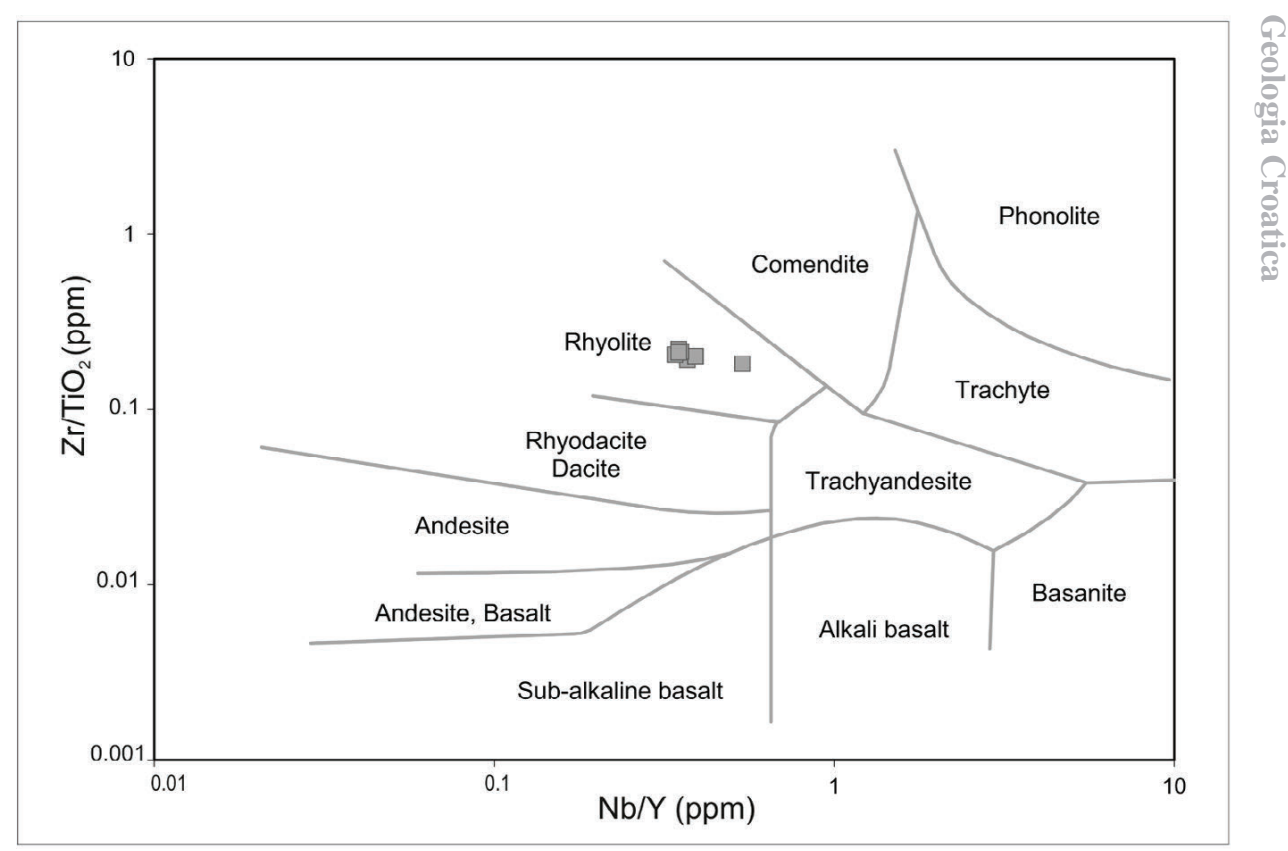

The marl samples were plotted between the idealized compositions of smectite and illite/muscovite, implying that the source rocks underwent an intermediate degree of weathering.

\subsubsection{Trace elements}

The chemical composition and element ratios of samples critical for understanding provenance, such as $\mathrm{La} / \mathrm{Co}, \mathrm{Th} / \mathrm{Co}, \mathrm{Th} / \mathrm{Sc}, \mathrm{La} / \mathrm{Sc}$, $\mathrm{Th} / \mathrm{Cr}, \mathrm{Eu} / \mathrm{Eu}^{*}, \mathrm{LREE} / \mathrm{HREE}$, $\Sigma$ REE are given in Tab. 2. Values of the $\mathrm{La} / \mathrm{Co}, \mathrm{Th} / \mathrm{Co}, \mathrm{Th} / \mathrm{Sc}, \mathrm{La} / \mathrm{Sc}$, Th/Cr, and Eu/Eu* ratios correspond to the values for acid (Si-rich) rocks, according to CULLERS $(1994,2000)$. Figure 12. represents the REE plots of samples normalized to chondrite (TAYLOR \& McLENNAN, 1985).

All samples show LREE > HREE and a negative Eu-anomaly, which is in accordance with the $\mathrm{Eu} / \mathrm{Eu}^{*}$ ratio as indicators of the size of Eu-anomalies (COX et al., 1995). The sum of REE, depending on the carbonate content, varies in the analysed samples from 36-123 ppm, while the LREE/HREE ratios are more uniform (LREE/HREE $=5.8-7.3 \mathrm{ppm}$ ). High LREE/HREE ratio indicate predominantly acid (Si-rich) source rocks. Figure 13. shows $\mathrm{Nb} / \mathrm{Y}-\mathrm{Zr} / \mathrm{TiO}_{2}$ diagrams proposed by WINCHESTER \& FLOYD (1977) and illustrates that all the analysed samples plot to the rhyolite field, further suggesting acid (Si-rich) source rocks.

\subsubsection{Inferred tectonic setting}

La-Th-Sc and Th-Sc-Zr/10 diagrams proposed by BHATIA \& CROOK (1986) were used to determine tectonic settings (Fig. 14).

According to these diagrams, the Badennian and Sarmatian marls plot close to the average composition of the Upper Continental Crust (TAYLOR \& McLENNAN, 1985), and within the field of the Continental Island Arc, representing inter-arc, fore-arc, or back-arc basin, adjacent to a volcanic-arc developed on a thick continental crust or thin continental margins (BHATIA \& CROOK, 1986). The inferred tectonic position corresponds to the fact that the PBS was one of the Mediterranean basins that existed from the Miocene to the Pliocene (HORVATH \& ROYDEN, 1981; ROYDEN, 1988).
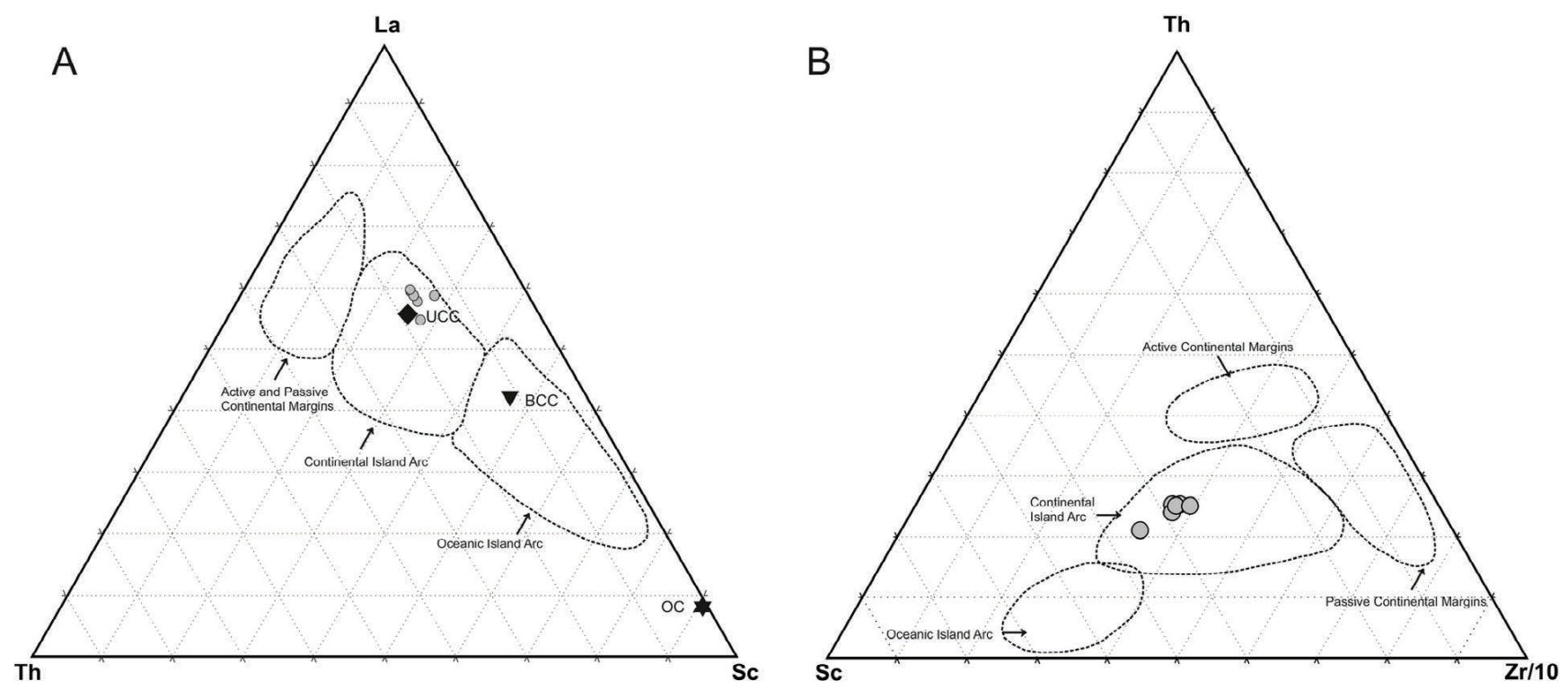

Figure 14. Discrimination plots La-Th-Sc and Th-Sc-Zr/10 for tectonic settings according to BHATIA \& CROOK (1986). Average composition of the Upper Continental Crust (UCC), Bulk Continental Crust (BCC) and Ocean Crust (OC) after TAYLOR \& McLENNAN (1985) are additionally plotted. 


\subsection{Biostratigraphy, palaeobiogeography, palaeoecology}

Lithologically and according to microfossil content, three different depositional environments can be distinguished (Fig. 2).

5.4.1. Late Badenian; lower part of the column

(0.0 - $5.2 \mathrm{~m}$; samples 1 - 5)

Silty marls dominate, followed by marls with intercalations of sand. The depositional environment varies from the distal dysoxic-anoxic shelf through a mud-dominated oxic shelf without terrigenous input to the proximal suboxic-anoxic shelf. Such conditions, affected by a humid climate, caused the development of a stratified water column and low oxic conditions at the sea bed. Low oxic conditions and a stratified environment were also confirmed by the presence of pyrite inclusions. These conditions are confirmed by the domination of buliminids, bolivinids and uvigerinids and the mass occurrence of Globigerina bulloides and Turborotalita quinqueloba (KOVÁČ et al., 2017 and references therein). Based on the different genera identified, the ostracod fauna from the KOS-I column can be defined as a shallow-water marine fauna. Some species of the genera Loxoconcha, Aminocythere and Xestoleberis tolerate lower water salinity, ranging from meso to oligohaline values. A Late Badenian age is determined based on the calcareous nannofossil assemblages (samples 1 and 5, Fig. 2) that identifies Subzone NN6c (MĂRUNȚEANU, 1999), as well as palynomorphs (samples 1 and 4, Fig. 2), foraminifera (samples 1-5, Fig. 2), and ostracods (sample 4, Supplement Tab. 2).

During the late Badenian, vegetation in the southernmost parts of the Central Paratethys was thermophilous, partly sub-humid under subtropical climatic conditions (KVAČEK et al., 2006; UTESCHER et al., 2007). Nevertheless, coccolith Umbilicosphaera is typical for the warm water, oligotrophic marine environments of subtropical to temperate climate (KINKEL et al., 2000; KRAMMER et al., 2006), while small Reticulofenestra are typical for oligotrophic, warm waters of lower latitudes (HAQ, 1980; RAHMAN \& ROTH, 1990). Umbilicosphaera jafari in assemblage with small Reticulofenestra species, noticed in sample 1, implies warmer and saltier shelf waters. This interval (Fig. 2; samples 1-2) probably belongs to the beginning of the late Badenian period of climate change from subtropical to warm, temperate humid climate recorded from $13.5 \mathrm{Ma}$ according to BÖHME (2003), known as the Middle Miocene Climatic Transition (MMCT). Occurrence of the dinocyst Achomosphaera andalousiensis in sample 4 points to an age younger than $13.3 \mathrm{Ma}-$ Serravallian (LOURENS et al., 2004). Cleistosphaeridium placacanthum and Cerebrocysta poulsenii together indicate an age no younger than the latest Serravallian or earliest Tortonian (JIMENEZ-MORENO et al., 2006). The HO of Cerebrocysta poulsenii is calibrated against basal C5r $(\sim 11.7 \mathrm{Ma})$ in Italy (ZEVENBOOM, 1995). An assemblage from the lower part (sample 1) is very similar to an assemblage from the Cerebrocysta poulsenii Assemblage Biozone of JIMENEZ-MORENO et al. (2006). They stated that the Cpo Zone indicates a late early Serravallian age and lies within nannofossil Zone NN6, as we detected here, and the Bolivina-Bulimina Zone of the regional benthic eco-zonation of GRILL (1941). This zone is also a correlative of the Achomosphaera andalousiensis (Aan) Interval Zone in the Mazzapiedi and Cassinasco sections of northwest Italy of Late Serravalian age (ZEVENBOOM, 1995). However, JIMENEZMORENO et al (2006) assigned this zone to the latest Badenian (late early Serravallian) in the Central Paratethys based on other fossils. The absence of agglutinated species with a dominance of Bulimina spp. and Bolivina spp. in the foraminiferal assemblage suggests a late Badenian age as well (PAULISSEN et al., 2011). The oceanic to outer neritic Nematosphaeropsis labyrinthus suggests that relatively open-marine conditions existed, which is in accordance with palynofacies that indicate a dysoxic-anoxic shelf environment (Fig. 6). Among the foraminifera (sample 1-6), morphogroups M4 and M5 dominate. The presence of the aforementioned unicameral foraminifera also indicates a late Badenian age (POPESCU \& CRIHAN, 2004). The main characteristic of this assemblages is its infaunal lifestyle in the muddy sediments mostly restricted to a shelf and slope environment (LI \& McGOWRAN, 1994). They prefer high productivity or a cold water environment (LI \& McGOWRAN, 1994), which is probably a consequence of a periodic influx of the cold Mediterranean current that affected the climate as well as humid periods under the subtropical climate detected here. The proportions of juveniles/adults and valves/carapaces of ostracods in the sedimentary record provide an estimate of wave energy during deposition (WHATLEY, 1988 and BOOMER et al., 2003). Higher energy conditions lead to the removal of smaller juvenile valves and cause the disarticulation of carapaces. Previous research showed that this relationship is autochthonous and characterizes the environment in which it is found when most ontogenetic stages are present in samples (WHATLEY, 1988; BOOMER \& EISENHAUER, 2002). In all samples of KOS-I column valves and a few fragments were found. In three samples (KOS-I 2, 4 and 5) juvenile valves are dominant. The population structure suggested that ostracods from the KOS-I column are allochthonous. Most of them are transported from a high-energy environment, and deposited in a low-energy environment. Resediment ostracods can be readily distinguished by examining adult to juvenile ratios. The ratio of adults and juveniles, as well as their general low frequency, suggests unfavourable conditions for the development of ostracods. Finer grained particles, such as juvenile valves, are more readily transported over greater distances such as transported assemblages have cleary skewed adult to the juvenile ratio (LORD et al., 2012). Besides, a small portion of foraminifera morphogroups M1 and M2 also suggests reworking from the shallower, well-oxygenated environment.

\subsubsection{Thin layer of clayey limestone (5.70 - $6.05 \mathrm{~m}$; sample 6$)$}

Restricted marine conditions are inferred from the low species richness of the dinocyst assemblages, but some oceanic influence was present as indicated by the rare occurrence of Impagidinium species in sample 6. According to JIMENEZ-MORENO et al. (2006), the Cerebrocysta poulsenii Assemblage Biozone (Cpo) reflects shallowing of the sea, before the emergence and erosion that led to the unconformity between the $\mathrm{Cpo}$ and $\mathrm{Cpl}$ zones at the Badenian-Sarmatian boundary. A general cooling trend appears as reflected by an increasing role of deciduous elements. Sometimes it overlaps with the lowermost Sarmatian, which is floristically barely distinguishable (KVAČEK et al., 2006). Based on calcareous nannofossils, a cooling event defines the Badenian/ Sarmatian transition as recorded in Subzone NN6c, while max. regression at the base of NN6d, close to the base of the Sarmatian (GALOVIĆ, 2017; GALOVIĆ, 2020), which is in accordance with HOHENEGGER et al. (2014). Sample 6 has not been adequate for calcareous nannofossils, but this interval could apply to Subzone NN6d, and stress developments recognised near the Badenian/Sarmatian boundary. A characteristic feature of the period is the predominance of Coniferae pointing to extrazonal mountain forests. 
The stressed marine environment is confirmed by prasinophytes. Some prasinophytes are "disaster species" because of their ability to survive in a stressed environment. They have a short-lived population increase, and they are most often replaced by opportunists (HARRIES et al., 1996, VAN DE SCHOOTBRUGGE et al., 2007). The environment was probably stressful, and the assemblage was dominated by disaster species which explains the co-occurrence of prasinophyte phycomata and redeposited dinocysts. Lingulodinium machaerophorum is restricted to coastal regions and regions in the vicinity of continental margins. High relative abundances can be observed in sediments near upwelling cells or below river discharge plumes or in highly stratified waters (ZONNEVELD et al., 2013).

Domination of foraminifera morphogroups M3 and M6 also suggests stressful and unfavourable environmental conditions. Small-sized and fragile tests of Cibicidoides species and prevailing Ammonia species are considered to be pioneer specimens. Based on all the investigated palaeontological data the Badenian/ Sarmatian boundary in the KOS-I column is in line with the proposed position of the boundary (Fig. 2).

5.4.3. Early Sarmatian; upper part of the column (6.05 - $23.50 \mathrm{~m}$; samples 7 - 15)

Marls dominate, followed by silty marls with intercalations of clayey limestone in the lower part to calcitic marls in the upper part.

Small, microperforate planktonic foraminifera species of the genera Tenutellinata and Tenuitella (indicative of the uppermost Badenian - the lowermost Sarmatian, according to FILIPESCUE and SILYE (2008)) point to the aforementioned stress conditions that occurred in Paratethys at $12.73 \mathrm{Ma}$ (HOHENEGGER et al. 2014), but here probably reworked from the earlier interval during the beginning of the transgression. Adult Badenian redeposited valves of the ostracod species Bosquetina carinella, Grinioneis haidingeri, Costa sp., Semicytherura filicata, Olimfalunia? plicatula, Tenedocythere slebrosa, Tenedocythere sulcatopunctata, occur in samples 7, 8, 11 and 13 . These species are very common in the Badenian deposits of the North Croatia Basin (HAJEK-TADESSE \& PRTOLJAN, 2011; VESEL LUKIĆ \& HAJEK-TADESSE, 2017) and wider area (ZORN, 2003, 2004; GROSS, 2006; GEBHARDT et al., 2009). Ostracod species including: Amnicythere sp. Cnestocythere truncata, Callistocythere cf. postvallata, Aurila cf. merita, Aurila cf. notata, Loxocorniculum hastatum, identified in the samples of the KOS-I column, are known from Sarmatian deposits of the wider area (GROSS, 2006; TÓTH, 2008). Sample 7 has not been adequate for calcareous nannofossils nor for palynomorphs, which is supportedby aforementioned intermediate weathering and reworked shallow water ostracods and forams (Fig. 2).

Following the lowstand in the early Sarmatian, sea level rose in Paratethys at ca. 12.5 Ma (KOVÁĆ et al., 2001) which influenced connections with the Mediterranean Sea and Indo-Pacific Ocean (GALOVIĆ, 2017 and references therein). Occurrence of the Sarmatian index species Nonion bogdanowiczi in sample 7 characterised the Sarmatian age. An early Sarmatian age is confirmed in sample 9 based on assemblages of calcareous nannofossils that identify Subzone NN7a (Fig. 2). The appearance of Discoaster kugleri in the assemblage with rare Calcidiscus pataecus, Helicosphaera walbersdorfensis, Rhabdosphaera spp. and Pontosphaera spp. characterises Subzone NN7a (GALOVIĆ, 2019). The base of Zone NN7 for Paratethys is close to the
$\mathrm{FO}_{\text {(global) }}$ D. hexapleuros at $12.186 \mathrm{Ma}$, De KAENEL et al. (2017) and possibly sets the sample 9 close to 12.18 Ma for Paratethys (GALOVIĆ, 2020 and references therein) (Fig. 2).

According to JIMENEZ-MORENO et al. (2006), the Cleistosphaeridium placacanthum Assemblage Biozone (Cpl), contains a low diversity assemblage indicating environmentally unfavourable conditions for most marine dinoflagellates. They correlate this event to the shallow depths and oscillating environmental conditions of the early Sarmatian. A similar assemblage is also found in sample 9 from the KOS-I column. Impagidinium spp. and Nematosphaeropsis labyrinthus disappeared there, indicating marginal marine environments also documented by the common occurrence of the genus Batiacasphaera (GEDL, 2005). High relative abundances of Lingulodinium machaerophorum indicate enhanced nutrient levels and hyposaline conditions with seasonal stratifications (JIMENEZ-MORENO et al., 2006)., while increments of the coccolith $R$. producta, as in high latitudes (WEI \& THIERSTEIN, 1991), indicates periods of weaker upwelling and warmer surface water. Enhanced species diversity in Zone NN7 implies a deeper and more stable environment.

The increase of Coccolithus pelagicus and small Reticulofenestra species in the upper part (Fig. 2) may be interpreted as the continues influence of weaker upwelling waters that slightly induced productivity extended from the margin, where a warmer surface current along the outer shelf and upper slope appears during the winter period, similar to the present west coast of Portugal (CACHAO \& MOITA, 2000).

\section{CONCLUSIONS}

1. The lithostratigraphic Hrvatska Kostajnica column (KOS-I) represents continuous sedimentation from the late Badenian to the early Sarmatian. An interpretation of the depositional history was performed based on the integration of data from the sedimentological fieldwork, mineralogical, geochemical and palaeobiological (calcareous nannofossil, foraminiferas, ostracods, palynomorphs) analyses that suggest marine, offshore sedimentation.

2. The mineral composition of pelitic sedimentary rocks is common for Middle Miocene deposits. However, the appearance of smectite indicates possible local volcanic activity in this period, while the presence of minerals from the clinoptilolite/heulandite series indicates a local source of material. Provenance analyses based on the chemical composition show that the Badenian-Sarmatian marls were predominantly formed by the weathering of acidic (Si-rich) source rocks in the Continental Island Arc area.

3. The investigated column was recorded from the subtropical late Badenian to a warmtemperate climate of early Sarmatian. A high rate of reworked microfossil species, especially foraminifera, together with small changes in the sedimentological composition and lack of significant tectonic features make it difficult to precisely define the Badenian/Sarmatian boundary. The biostratigraphy based on the fossil assemblages shows that the Badenian/ Sarmatian boundary could be located within the column at $6.05 \mathrm{~m}$ from the base.

4. The position of the Hrvatska Kostajnica column (KOS-I) at the edge of the NCB shows different attributes in depositional settings and ecological conditions than the rest of the area studied to date (the Slavonian Mts. and Mt. Medvednica). The main feature of the KOS-I column, concerning fossil assemblage, reworking, can also be explained due to its position mostly detected at the edge of the basin. 


\section{ACKNOWLEDGEMENT}

This study was co-financed by the project INTERREG - IPA CBC Croatia-Bosnia and Herzegovina-Montenegro 2014 - 2020 "safEarth" (Transnational advanced management of land use risk through landslide susceptibility maps design). We are very grateful to Stjepan ĆORIĆ (Geological Survey of Austria) and Anonymous Reviewer for their valuable and helpful reviews.

\section{REFERENCES}

AVANIĆ, R., KOVAČĆĆ, M., PAVELIĆ, D., MIKNIĆ, M., VRSALJKO, D., BAKRAČ, K. \& GALOVIĆ, I. (2003): The Midle and Upper Miocene facies of Mt. Medvednica (Northern Croatia).- In: VLAHOVIĆ, I. \& TIŠLJAR, J. (eds.): Evolution of Depositional Environments from Paleozoic to the Quarternary in the Karst Dinarides and the Pannonian Basin, Field Trip Guidebook, 22nd IAS Meeting of Sedimentology. Institute of Geology, Zagreb, 167-172.

AVANIĆ, R, KOVAČIĆ, M., PAVELIĆ, D. \& PEH, Z. (2018): The Neogene of Hrvatsko zagorje.- In: TIBLJAŠ, D., HORVAT, M., TOMAŠIĆ, N., MILEUSNIĆ, M. \& GRIZELJ, A. (eds.): 9th Mid-European Clay Conference, Zagreb, Conference book - Field Trip Guide book, Croatian Geological Society, Zagreb, 128-129.

ANDERSSON, P.O.D., WORDEN, R.H., HODGSON, D.M. \& FLINT, S. (2004): Provenance evolution and chemostratigraphy of a Palaeozoic submarine fan-complex: Tanqua Karoo Basin, South Africa.- Marine Petrol Geo, 21, 555-577. doi: 10.1016/j. marpetgeo.2004.01.004

BAKRAČ, K., KOCH, G. \& SREMAC, J. (2012): Middle and Late Miocene palynological biozonation of the south-western part of Central Paratethys (Croatia).- Geol. Croat., 65/2, 207-222. doi: 10.4154/GC.2012.12

BHATIA, M.R. \& CROOK, K.A.W. (1986): Trace Element Characteristics of Greywackes and Tectonic Setting Discrimination of Sedimentary Basins. Contrib.- Mineral Petr., 92, 181-193.

BÖHME, M. (2003): The Miocene Climatic Optimum: evidence from ectothermic vertebrates of Central Europe.- Palaeogeogr. Palaeoclimatol. Palaeoecol., 195, 389-401. doi: 10.1016/S0031-0182(03)00367-5

BOHN-HAVAS, M. \& ZORN, I. (2002): Biostratigraphic correlation of planktonic gastropods in the Neogene of the Central Paratethys. Bulletin T. CXXV. de l'Académir Serbe des Sciences et des Arts, Classe des Sciences mathématiques et naturelles.Sciences naturelles Sci. naturelles, 41, 199-207.

BOOMER, I. \& EISENHAUER, G. (2002): Ostracod faunas as palaeoenvironmental indicators in marginal marine environments.- In: HOLMES, J.A. \& CHIVAS, A.R. (eds.): The Ostracoda: Applications in Quaternary Research. Geophysical Monograph, 131, American Geophysical Union, Washington, DC. 135-149. doi: 10.1029/131GM07

BOOMER, I. HORNE, D.J. \& SLIPPER, I. (2003): The use of ostracodes in paleo-environmental studies, or what can you do with an ostracod shell?- The Palaeontological Society Papers, 9, 153-180.

BOŠNJAK, M., SREMAC, J., VRSALJKO, D., AŠČIĆ, Š. \& BOSAK, L. (2017): The Miocene 'Pteropod Event' in the SW Part of the Central Paratethys (Medvednica Mt., Northern Croatia).- Geol. Carpath., 68/4, 329-49. doi: 10.1515/geoca-2017-0023

BRLEK, M., ŠPIŠIĆ, M., BRČIĆ, V., MIŠUR, I., KUREČIĆ, T., MIKNIĆ, M., AVANIĆ, R., VRSALJKO, D. \& SLOVENEC, D. (2016): Mid-Miocene (Badenian) transgression on Mesozoic basement rocks in the Mt. Medvednica area of northern Croatia.Facies, 62/3, 1-21. doi: 10.1007/s10347-016-0470-z.

BRLEK, M., KUTTEROLF, S., GAYNOR, S., KUIPER, K., BELAK, M., BRČIĆ, V.,HOLCOVA, K., WANG, K., BAKRAČ, K., HAJEK-TADESSE, V., MIŠUR, I., HORVAT, M., ŠUICA, S. \& SCHALTEGGER, U. (2020): Miocene syn-rift evolution of the North Croatian Basin (Carpathian-Pannonian Region): new constraints from Mts. Kalnik and Požeška gora volcaniclastic record with regional implications.- Int. J. Earth Sci. doi: 10.1007/s00531-020-01927-4

CACHAO, M. \& MOITA, M.T. (2000): Coccolithus pelagicus, a productivity proxy related to moderate fronts off Western Iberia.- Mar. Micropaleontol., 39, 131-155. doi: $10.1016 / \mathrm{S} 0377-8398(00) 00018-9$

CHANG, L.L.Y., HOWIE, R.A. \& ZUSSMAN, M.A. (1998): Rock forming minerals, Vol. 5B, Non-silicates: Sulphates, Carbonates, Phosphates, Halides.- The Geological Society Geol. Soc., London, 383 p.

CHAMLEY, H. (1989): Clay sedimentology.- Springer-Verlag. Berlin, 623 p. doi: 10.1007/978-3-642-85916-8

CICHA, I., RÖGL, F., RUPP, C. \& CTYROKA, J. (1998): Oligocene - Miocene Foraminifera of the Central Paratethys.- Abhandlungen Der Senckenbergischen Naturforschenden Gesellschaft, 549, 1-153.

ĆORIĆ, S., PAVELIĆ, D., RÖGL, F., MANDIC, O., VRABAC, S., AVANIĆ, R., JERKOVIĆ, L. \& VRANJKOVIĆ, A. (2009): Revised Middle Miocene datum for initial marine flooding of North Croatian Basins (Pannonian Basin System, Central Paratethys).- Geol. Croat., 62/1, 31-43. doi: 10.4154/GC.2009.03.

COX, R., DENGATE, J. \& CULLERS, R.L. (1995): The influence of sediment recycling and basement composition on evolution of mudrock chemistry in the southwestern
United States.- Geochim. Cosmochim. Acta, 59, 2919-2940. doi: 10.1016/00167037(95)00185-9

CULLERS, R.L. (1994): The chemical signature of suorce rocks in size fractions of Holocene stream sediment derived from metamorphic rocks in the Wet Mountains region, Colorado U.S.A.- Chem. Geol., 113, 327-343.

CULLERS, R.L. (2000): The geochemistry of shales, siltstones and sandstones of Pennsylvanian-Permian age, Colorado, USA: Implications for provenance and metamorphic studies.- Lithos 51, 181-203. doi: 10.1016/S0024-4937(99)00063-8

CVETKOVIĆ, M., MATOŠ, B., RUKAVINA, D., KOLENKOVIĆ MOČILAC, I., SAFTIĆ, B., BAKETARIĆ, T., BAKETARIĆ, M., VUIĆ, I., STOPAR, A., JARIĆ, A. \& PAŠKOV, T. (2019): Geoenergy potential of the Croatian part of Pannonian Basin: insights from the reconstruction of the pre-Neogene basement unconformity.J. Maps., 15, 651-661. doi: 10.1080/17445 647.2019.16450 52

De KAENEL, E., BERGEN, J., BROWNING, E., BLAIR, S. \& BOESIGER, T. (2017): Uppermost Oligocene to Middle Miocene Discoaster and Catinaster taxonomy and stratigraphy in the circum North Atlantic Basin: Gulf of Mexico and ODP Leg 154.J. Nannoplankton Research J. Nano. Res., 37, 215-244.

De LEEUW, A., BUKOWSKI, K., KRIJGSMAN, W. \& KUIPER, K.F. (2010): Age of the Badenian salinity crisis; impact of Miocene climate variability on the circumMediterranean region.- Geology, 38/8, 715-718. doi: 10.1130/G30982.1

DUMITRIU, S., LOGHIN, S., DUBICKA, Z., MELINTE-DOBRINESCU, M.C., PARUCH-KULCZYCKA, J. \& IONESI, V. (2017): Foraminiferal, Ostracod, and Calcareous Nannofossil Biostratigraphy of the Latest Badenian - Sarmatian Interval (Middle Miocene, Paratethys) from Poland, Romania and the Republic of Moldova.Geol. Carpath., 68/5, 419-44. Doi: 10.1515/geoca-2017-0028

FILIPESCU, S. \& SILYE, L. (2008): New Paratethyan Biozones of Planktonic Foraminifera Described from the Middle Miocene of the Transylvanian Basin (Romania).Geol. Carpath., 59/6, 537-44.

FILIPESCU, S., MICLEA, A., GROSS, M., HARZHAUSER, M., ZÁGORŠEK, K. \& JIPA, C. (2014): Early Sarmatian Paleoenvironments in the Easternmost Pannonian Basin (Borod Depression, Romania) Revealed by the Micropalaeontological Dana. - Geol. Carpath, 65/1, 67-81. doi: 10.2478/geoca-2014-0005

GALOVIĆ, I. (2020). Sarmatian biostratigraphy of a marginal sea in northern Croatia based on calcareous nannofossils.- Mar. Micropaleontol, doi.org/10.1016/j.marmicro.2020.101928.

GALOVIĆ, I. (2003): Kremični i vapnenački nanofosičli sarmatskih naslaga Medvednice [Siliceous and calcareous nannofossils from Sarmatian beds in the Mt. Medvednica. - in Croatian, with an English Abstract].- Unpubl. Master Thesis, Faculty of Science, University of Zagreb, $82 \mathrm{p}$.

GALOVIĆ, I. (2017): Sarmatian calcareous nannofossil assemblages in the SW Paratethyan marginal marine environments: implications for palaeoceanography and the palaeoclimate.- Prog. Oceanogr., 156, 209-220. doi: 10.1016/j.pocean.2017.05.011

GALOVIĆ, I. (2019): Sarmatian (Late Serravallian-Early Tortonian) biostratigraphy: A case-study in a marginal sea.- In: BYBELL, L.M. (eds.): 17. INA Conf.-Santos, Brazil. J. Nano. Res., 39-39.

GALOVIĆ, I. \& YOUNG, J. (2012): Revised taxonomy and stratigraphy of Middle Miocene calcareous nannofossils of the Paratethys.- Micropaleontology, 58, 305-334.

GARCIA, D., FONTEILLES, M. \& MOUTTE, J. (1994): Sedimentary fractionations between $\mathrm{Al}, \mathrm{Ti}$, and $\mathrm{Zr}$ and the genesis of strongly peraluminous granites.- J. Geol, $102,411-322$.

GEBHARDT, H., ZORN, I. \& ROETZEL, R. (2009): The initial phase of the EarlySarmatian (Middle Miocene) transgression. Foraminiferal and ostracod assemblages from an incised valley fill in the Molasse Basin of Lower Austria.-Austrian J. Earth Sc., 102, 100-119.

GEDL, P. (2005): In situ and recycled dinoflagellate cysts from Middle Miocene deposits at Bêczyn, Carpathian Foredeep, Poland.- Stud. Geol. Polon., 124, 371-394.

GEDL, P., PERYT, D. \& PERYT, T.M. (2016): Foraminiferal and Palynological Organic Matter Records of the Upper Badenian (Middle Miocene) Deposits at Anadoly (Marginal Part of the Ukrainian Carpathian Foredeep Basin).-- Geol. Q., 60/2, 517-536. doi: $10.7306 /$ gq.1300.gedl

GRADSTEIN, F.M., OGG, J.G., SCHMITZ, M.D. \& OGG, G. (2012): The Geologic Time Scale 2012.- Elsevier, Amsterdam, $1144 \mathrm{p}$.

GRILL, R. (1941): Stratigraphische Untersuchungen mit Hilfe von Mikrofaunen im Wiener Becken und den benachbarten Molasse-Anteilen.- Öl Kohle, 37, 595-602.

GRIZELJ, A., PEH, Z., TIBLJAŠ, D., KOVAČIĆ, M. \& KUREČIĆ, T. (2017): Mineralogical and geochemical characteristics of Miocene pelitic sedimentary rocks from the south-western part of the Pannonian Basin System (Croatia): Implications for provenance studies.- Geosci. Front., 8/1, 65-80. doi:10.1016/j.gsf.2015.11.009

GROSS, M. (2006): Mittelmiozäne Ostracoden aus dem Wiener Becken (Badenium/Sarmatium, Österreich).- Österr. Akad. Wissenschaft., Schriften reihe der Erdwiss. Komm. Sonderbd, Wien, 1, 1-224.

HAJEK-TADESSE, V. \& PRTOLJAN, B. (2011): Badenian ostracoda from the Pokupsko area (Banovina, Croatia).- Geol. Carpath., 62, 447-461. doi: 10.2478/v10096-0110032-9

HAJEK-TADESSE, V., BELAK, M., SREMAC, J., VRSALJKO, D. \& WACHA, L. (2009): Lower Miocene ostracods from the Sadovi section (Mt. Požeška gora, Croatia).- Geol. Carpath., 60/3, 251-262. 
HAQ, B.U. (1980): Biogeographic history of Miocene calcareous nannoplankton and paleooceanography of the Atlantic Ocean.- Micropaleontology, 26, 414-443.

HARRIES, P.J., KAUFFMAN, E.G. \& HANSEN, T.A. (1996): Models for biotic survival following mass extinction.- In: HART, M.B. (eds.): Biotic Recovery from Mass Extinction Events. Geol. Soc. London. Special Publications, 102, 41-60. doi: 10.1144/GSL.SP.1996.001.01.03

HARTMAN, G. \& PURI, H.S. (1974): Summary of neontological and palaeontological classification of Ostracoda.- Mitt. Hamburg. Zool. Mus. Inst., 70, 7-73.

HARZHAUSER, M. \& PILLER, W.E. (2007): Benchmark dana of a changing sea - Paleogeography, Paleobiogeography and events in the Central Paratethys during the Miocene.- Paleogeogr. Aleoclimatol. Paleoecol., 253, 8-31.

HIGH SCORE PLUS, VERSION 4.5 (4.5.0.22741) (2016): PANalytical B.V.. Almeo, The Netherlands.

HILGEN, F.J., LOURENS, L.J., VAN DAM, J.A. \& OGG, J.G. (2012): The Neogene period.- In: GRADSTEIN, F.M., SCHMITZ, M.D. \& OGG, G.M. (eds.): The Geologic Time Scale 2012. Vol. 2. Elsevier, Amsterdam, 923-978. doi: 10.1016/B9780-444-59425-9.00029-9

HOHENEGGER, J., ĆORIĆ, S. \& WAGREICH, M. (2014): Timing of the Middle Miocene Badenian Stage of the Central Paratethys.- Geol. Carpath., 65, 55-66. doi: 10.2478/geoca-2014-0004

HORNE, D.J., COHEN, A. \& MARTENS, K. (2002): Taxonomy, morphology and biology of Quaternary and Living Ostracoda-- In: HOLMES, J.A. \& CHIVAS, A.R. (eds.): The Ostracoda. Applications in Quaternary Research. Geophys. Monograph Ser., 131, 5-6. doi: 10.1029/131GM02

HORVÁTH, F. \& ROYDEN, L.H. (1981): Mechanism for the Formation of the IntraCarpathian Basins: A Review.- Earth Sci. Reviews, 3-4, 307-316.

JACKSON, M.L. (1956): Soil chemical analysis - Advanced course. Medison. Wisconsin Wisc., Published by the author, $894 \mathrm{p}$.

JIMÉNEZ-MORENO, G., HEAD, M.J. \& HARZHAUSER, M. (2006): Early and Middle Miocene dinoflagellate cyst stratigraphy of the central Paratethys, central Europe.- J. Micropalaeontol., 25, 113-139. doi: 10.1144/jm.25.2.113

JOVANOVIĆ, Č. \& MAGAŠ, N. (1986a): Osnovna geološka karta SFRJ 1:100000, Tumač za list Kostajnica [Basic Geological Map of SFRY, 1:100000, Geology of the Kostajnica sheet - in Croatian].- Savezni geološki zavod, Beograd, $46 \mathrm{p}$

JOVANOVIĆ, Č. \& MAGAŠ, N. (1986b): Osnovna geološka karta M 1:100.000, list Kostajnica [Basic Geological Map of SFRY, 1:100000. Kostajnica sheet - in Croatian].- Savezni geološki zavod, Beograd.

KINKEL, H., BAUMANN, K.H. \& CEPEK, M. (2000): Coccolithophores in the equatorial Atlantic Ocean: response to seasonal and Late Quaternary sueface water variability.- Mar. Micropaleontol., 39, 87-112. doi: 10.1016/S0377-8398(00)00016-5

KOVÁC̆, M., ANDREYEVA-GRIGOROVICH, A., BAJRAKTAREVIĆ, Z., BRZOBOHATÝ, R., FILIPESCU, S., FODOR, L., HARZHAUSER, M., NAGYMAROSY, A., OSZCZYPKO, NI, PAVELIĆ, D., RÖGL, F., SAFTIĆ, B., SLIVA, L. \& STUDENCKA, B. (2007): Badenian evolution of the Central Paratethys Sea: paleogeography, climate and eustatic sea-level changes.- Geol. Carpath., 58/6, 579-606.

KOVÁČ, M., HALÁSOVÁ, E., HUDÁČKOVÁ, N., HOLCOVÁ, K., HYŽNÝ, M., JAMRICH, M. \& RUMAN, A. (2018): Towards better correlation of the Central Paratethys regional time scale with the standard geological time scale of the Miocene Epoch.- Geol. Carpath., 69/3, 283-300. doi: 10.1515/geoca-2018-0017

KOVÁČ, M., HUDÁČKOVÁ, N., HALÁSOVÁ, E., KOVÁČOVÁ, M., HOLCOVÁ, K., OSZCZYPKO-CLOWES, M., BÁLDI, K., LESS, G., NAGYMAROSY, A., RUMAN, A., KLUČIAR, T. \& JAMRICH, M. (2017): The Central Paratethys palaeoceanography: A water circulation model based on microfossil proxies, climate, and changes of depositional environment-- Acta Geol. Slovaca, 9/2, 75-114.

KOVÁC̆, M., NAGYMAROSY, A., HOLCOVÁ, K., HUDÁČKOVÁ, N. \& ZLINSKÁ, A. (2001): Paleogeography, paleoecology and eustasy: Miocene 3rd order cycles of relative sea-level changes in the Western Carpathian North Pannonian Basins.-Acta Geol. Hung., 44, 1-45.

KOVAČIĆ, M., HORVAT, M., PIKIJA, M. \& SLOVENEC, D. (2011): Composition and provenance of Neogene sedimentary rocks of Dilj gora Mt. (south Pannonian Basin, Croatia).- Geol. Croat., 64/2, 121-132.

KRAMMER, R., BAUMANN, K.-H. \& HENRICH, R. (2006): Middle to late Miocene fluctuations in the incipient Benguela upwelling system revealed by calcareous nannofossils assemblages (ODP Site 1087A).- Palaeogeogr. Palaeoclimatol. Palaeoecol., 230, 319-334. doi:10.1016/j.palaeo.2005.07.022

KVAČEK, Z., KOVÁČ, M., KOVAR-EDER, J., DOLÁKOVÁ, N., JECHOREK, H., PARASHIV, V., KOVÁČOVÁ, M. \& SLIVA, L. (2006): Miocene evolution of landscape and vegetation in the Central Paratethys.- Geol. Carpath., 57/4, 295-310.

LI, Q. \& MCGOWRAN, B. (1994): Evolutionary morphologicalchanges in the new genus Duoforisa: Implication forclassification and habitat of unilocular foraminifera.-Alcheringa, $18,121-134$

LIPPMANN, F. (1973): Sedimentary carbonate minerals.- Springer - Verlag, Berlin, 228 p. doi: $10.1007 / 978-3-642-65474-9$

LORD, A.R., BOOMER, I., BROUWERS, E. \& WHITTAKER, J.E. (2012): Ostracod taxa as palaeoclimate indicators in the quaternary.- Dev Quat Sci., 17, 37-45. doi: 10.1016/B978-0-444-53636-5.00003-2
LOURENS, L., HILGEN, F., SHACKLETON, N.J., LASKAR, J. \& WILSON, D. (2004): The Neogene Period.- In: GRADSTEIN, F., OGG, J. \& SMITH, A. (eds.): A Geological Time Scale 2004. Cambridge Univ. Press, Cambridge, U.K., 409-440. doi: $10.1017 / \mathrm{CBO} 9780511536045.022$

MANDIC, O., DE LEEUW, A., BULIĆ, J., KUIPER, K.F., KRIJGSMAN, W. \& JURIŠIĆPOLŠAK, Z. (2012): Paleogeographic evolution of the southern Pannonian Basin: $40 \mathrm{Ar} / 39 \mathrm{Ar}$ age constraints on the Miocene continental series of northern Croatia. Int. J. Earth Sci., 101, 1033-1046. doi: 10.1007/s00531-011-0695-6.

MANDIC, O., HAJEK-TADESSE, V., BAKRAČ, K., REICHENBACHER, B., GRIZELJ,A. \& MIKNIĆ, M. (2019a): Multiproxy reconstruction of the middle Miocene Požega palaeolake in the Southern Pannonian Basin (NE Croatia) prior to the Badenian transgression of the Central Paratethys Sea.- Palaeogeogr. Palaeoclimatol. Palaeoecol., 516, 203-219. doi:10.1016/j.palaeo.2018.12.003

MANDIC, O., RUNDIĆ, LJ., ĆORIĆ, S., PEZELJ, D., THEOBALT, D., SANT, K. \& KRIJGSMAN, W. (2019b): Age and mode of the middle Miocene marine flooding of the Pannonian Basin - constraints from central Serbia.- Palaios, 34, 71-95. doi: 10.2110/palo.2018.052

MANDIC, O., SANT, K., KALLANXHI, M.-E., ĆORIĆ, S., THEOBALT, D., GRUNERT, P., DE LEEUW, A. \& KRIJGSMAN, W. (2019c): Integrated bio-magnetostratigraphy of the Badenian reference section Ugljevik in southern Pannonian Basin - implications for the Paratethys history (middle Miocene, Central Europe).- Glob. Planet. Change, 172, 374-395. doi: 10.1016/j.gloplacha.2018.10.010

MARKOVIĆ, F. (2017): Miocenski tufovi Sjevernohrvatskoga bazena [Miocene tuffs from North Croatian Basin - in Croatian, with an English Abstract].- Unpubl. Master Thesis, Faculty of Science, University of Zagreb, 174 p.

MARKOVIĆ, S. (2002): Hrvatske mineralne sirovine [Croatian mineral resources - in Croatian].- Institute of geology, Zagreb, $543 \mathrm{p}$.

MARTINI, E. (1971): Standard Tertiary and Quaternary calcareous nannoplankton zonation.-In: FARINACCI, A. (ed.): Proceedings of the 2 Plank. Conf., Roma, 739-785.

MĂRUNȚEANU, M. (1999): Litho- and Biostratigraphy (calcareous nannoplankton) of the Miocene deposits from the outer Moldavides.- Geol. Carpath., 50, 313-324.

McLENNAN, S.M. (1993): Weathering and global denudation.- The Journal of Geology, 101, 295-303. doi: 10.1086/648222

MOORE, P.D., WEBB, J.A. \& COLLINSON, M. (1991): Pollen Analysis (second edition).- Blackwell Sci. Publication. London, $216 \mathrm{p}$.

MÜLLER, G., IRION, G. \& FOERSTNER, U. (1972): Formation and diagenesis of inorganic $\mathrm{Ca}-\mathrm{Mg}$ carbonates in the lacustrine environment.- Naturwissenschaften, 59/4, 158-164. doi: 10.1007/BF00637354

MURRAY, J.W. (2006): Ecology and applications of benthic foraminifera.- Cambridge University Press, Cambridge, UK, 426 p. doi: 10.1017/CBO9780511535529

NESBITT, H.W. \& YOUNG, G.M. (1982): Early Proterozoic climates and plate motions inferred from majorelement chemistry of lutites.- Nature, 299, 715-717.

NESBITT, H.W. \& YOUNG, G.M. (1984): Prediction of some weathering trends of plutonic and volcanic rocks based on thermodynamic and kinetic considerations.- Geochim. et Cosmochim. Ac., 48, 1523-1534. doi: 10.1016/0016-7037(84)90408-3

PAMIĆ, J., McKEE, E. H., BULLEN, T. \& LANPHERE, M.A. (1995): Tertiary volcanic rocks from Southern Panonnian Basin, Croatia.- Int. Geol. Rev., 37, 259-283.

PAULISSEN, W., LUTHI, S., GRUNERT, P., ČORIĆ, S. \& HARZHAUSER, M. (2011): Integrated High-Resolution Stratigraphy of a Middle to Late Miocene Sedimentary Sequence in the Central Part of the Vienna Basin.- Geol. Carpath., 62/2, 155-169. doi: 10.2478/v10096-011-0013-z.

PAVELIĆ, D. (2001): Tectonostratigraphic model for the North Croatian and North Bosnian sector of the Miocene Pannonian Basin System.- Basin Res., 13, 359-376. doi: 10.1046/j.0950-091x.2001.00155.x

PAVELIĆ, D. \& KOVAČIĆ, M. (1999): Lower Miocene alluvial deposits of the Požeška Mt. (Pannonian Basin, northern Croatia): cycles, megacycles and tectonic implications.- Geol. Croat., 52, 67-76.

PAVELIĆ, D. \& KOVAČIĆ, M. (2018): Sedimentology and stratigraphy of the Neogene rift-type North Croatian Basin (Pannonian Basin System, Croatia): A review.- Mar. Petrol. Geol., 91, 455-469. doi: 10.1016/j.marpetgeo.2018.01.026

PAVELIĆ, D., MIKNIĆ, M. \& SARKOTIĆ ŠLAT, M. (1998): Early to Middle Miocene facies succession in lacustrine and marine environments on the southwestern margin of the Pannonian basin system.- Geol. Carpath., 49, 433-443.

PDF-4/Minerals (2020): International Centre for Diffraction Data. SN: MIND 2001334545.

PERYT, D., GEDL, P. \& PERYT, T.M. (2014): Foraminiferal and Palynological Records of the Late Badenian (Middle Miocene) Transgression in Podolia (Shchyrets near Lviv, Western Ukraine).- Geol. Q., 58/3, 465-84. doi: 10.7306/gq.1195.

POPESCU, G. \& CRIHAN, I.M. (2004): Contribution to the knowledge of the calcareous unicameral foraminifera from the Middle Miocene of Romania.- Acta Palaeontol. Rom., 4, 403-421.

POPESCU, G. \& CRIHAN, I.M. (2005a): Middle Miocene Foraminifera from Romania: Order Buliminida, Part I.-Acta Palaeontol. Rom., 5, 379-96.

POPESCU, G. \& CRIHAN, I.M. (2005b): Middle Miocene foraminifera from Romania: order Buliminida, Part II.-Acta Palaeontol. Rom., 5, 397-412. 
POPESCU, G. \& CRIHAN, I.M. (2008): Contributions to the Knowledge of the Rotaliiform Foraminifera from the Marine Middle Miocene Deposits from Romania.Acta Palaeontol. Rom., 6/4, 287-324.

POPESCU, G. \& CRIHAN, I.M. (2011): Middle Miocene Globigerinas of Romania.Acta Paleontol. Rom., 7, 291-314. doi: 10.1016/j.bcp.2004.07.023.

RAHMAN, A. \& ROTH, P.H. (1990): Late Neogene paleoceanography and paleoclimatology of the Golf of Aden region based on calcareous nannofossils.- Paleoceanography, 5, 91-107.

RAO, P.C. (1996): Modern carbonates, tropical, temperate, polar. Introduction to sedimentology and geochemistry.- University of Tasmania, Tasmania, $206 \mathrm{p}$.

ROYDEN, L.H. (1988): Late Cenozoic Tectonics of the Pannonian Basin System.- In: ROYDEN L.H. \& HORVATH, I.F. (eds.): The Pannonian Basin. A study in Basin Evolution. AAPG Memoir, Tulsa, 45, 27-48.

ROYDEN, L.H., HORVATH, F., NAGYMAROSY, A. \& STEGENA, L. (1983): Evolution of the Pannonian Basin System 2, Subsidence and thermal history.- Tectonics, 2, 91-137. doi: 10.1029/TC002i001p00091

SCHMIDT, R.R. (1978): Calcareous nannofossils.- In: ZACHARIASSE, W.J., RIEDEL, W.R., SANFILIPPO, A., SCHMIDT, R.R., BROLSMA, M.J., SCHRADER, H.J., GERSONDE, R. DROOGER, M.M. \& BROEKMAN, J.A. (eds.): Micropalaeontological counting methods and techniques-an expercise on an eight metres section of the Lower Pliocene of Capo Rossello, Sicily. Utrecht Micropalaeontological Bulletins, Utrecht: Schotanus and Jens, 241-265.

SCHÜTZ, K., HARZHAUSER, M., RÖGL, F., ĆORIĆ, S. \& GALOVIĆ, I. (2007): Foraminiferen und Phytoplankton aus dem unteren Sarmatium des südlichen Wiener Beckens (Petronell, Niederösterreich).- Jahrbuch der Geologischen Bundesanstalt, $147,449-488$.

SCHULTZ, L.G. (1964): Quantitative interpretation of mineralogical composition from X-ray and chemical data for the Pierre Shale.- U. S. Geological Survey Professional Paper, 391-C, $31 \mathrm{p}$.

SHAMROCK, J.L., MUNOZ, E.J. \& CARTER, J.H. (2015): An improved sample preparation technique for calcareous nannofossils in organic-rich mudstones.- J. Nannoplankton Research, 35, 101-110.

SILYE, L. (2015): Sarmatian Foraminiferal Assemblages from Southern Transylvanian Basin and Their Significance for the Reconstruction of Depositional Environments.- Presa Universitară Clujeană, Cluj, 228 p.

STEININGER, F.F., MÜLLER, C. \& RÖGL, F. (1988): Correlation of Central Paratethys, Eastern Paratethys, and Mediterranean Neogene Stages.- In: ROYDEN, L.H. \& HORVATH, F. (eds.): The Pannonian Basins. A study in Basin Evolution. Am. Assoc. Petrol. Geol. Mem., 45, 79-87.

TAYLOR, S.R. \& McLENNAN, S.M. (1985): The Continental Crust: Its composition and evolution.- Blackwell, Oxford, $312 \mathrm{p}$.

TIŠLJAR, J. (2001): Carbonate and evaporite sedimentology.- Institut za geološka istraživanja, Zagreb, $375 \mathrm{p}$.

TÓTH, E. (2008): Sarmatian (Middle Miocene) ostracod fauna from. Zsámbék Basin, Hungary.- Geol. Pannonica, 36, 101-151.

TÓTH E., GÖRÖG, A., LÉCUYER, C., MOISSETTE, V.B. \& MONOSTORI, M. (2010): Palaeoenvironmental reconstruction of the Sarmatian (Middle Miocene) Central Paratethys based on the palaeontological and geochemical analyses of foraminifera, ostracods, gastropods and rodents.- Geol. Mag., 147/2, 299-314.

TYSON, R.V. (1995): Sedimentary Organic Matter. Organic Facies and Palynofacies.Chapman and Hall, London, 615 p. doi: 10.1007/978-94-011-0739-6

UTESCHER, T., DJORDJEVIC-MILUTINOVIC, D., BRUCH, B. \& MOSBRUGGER, V. (2007): Climate and vegetation changes in Serbia during the last $30 \mathrm{Ma}$-- Pa- laeogeogr. Palaeoclimatol. Palaeoecol., 253, 139-150. doi:10.1016/j.palaeo.2007.03.037

VAN DE SCHOOTBRUGGE, B., TREMOLADA, F., ROSENTHAL, Y., BAILEY, T.R., FEIST-BURKHARDT, S., BRINKHUIS, H., PROSS, J., KENT, D.V. \& FALKOWSKI, P.G. (2007): End-Triassic calcification crisis and blooms of organic-walled "disaster species".- Palaeogeogr. Palaeoclimatol. Palaeoecol., 244, 126-141. doi:10.1016/j.palaeo.2006.06.026.

VAN MORKHOVEN F.P.C.M. (1963): Post-Palaeozoic Ostracoda. Their morphology, taxonomy and economic use. Vol. II. Generic Descriptions.- Elsevier Publ. Co., Amsterdam/London/New York, 1-478.

VESEL LUKIĆ, M. \& HAJEK TADESSE, V. (2017): Badenian ostracods from Požeška gora and Papuk Mts.- In: HORVAT, M. \& WACHA, L. (eds.): 7th International Workshop Neogene of Central and South-Eastern Europe, Zagreb, Croatian Geological Society, 73-74.

WEAVER, C.E. (1989): Clays, Muds, and Shales.- Elsevier, Amsterdam, 721 p.

WEI, W. \& THIERSTEIN, H. R. (1991): Upper Cretaceous and Cenozoic calcareous nannofossils of the Kerguelen Plateau (Southern Indian ocean) and Prydz Bay (East Anatarctica).- In: BARRON, J. \& LARSEN, B. (eds.): Proceedings of the Ocean Drilling Program, Scientific Results, College Station, TX (Ocean Drilling Program), 119, 467-493. doi: 10.2973/odp.proc.sr.119.165.1991

WHATLEY, R.C. (1988): Population structure of ostracods: some general principles for the recognition of palaeoenvironments.- In: DE DECKKER, P., COLIN, J.P. \& PEYPOUQUET, J.P. (eds.): Ostracoda in the Earth Sciences. Elsevier, Amsterdam, 245-256.

WINCHESTER, J.A. \& FLOYD, P.A. (1977): Geochemical discrimination of different magma series and their differentiation products using immobile elements.-Chem. Geol., 20, 325-343. doi: 10.1016/0009-2541(77)90057-2

WOOD, G.D., GABRIEL, A.M. \& LAWSON, J.C. (1996): Palynological techniques: processing and microscopy.- In: JANSONIUS, J. \& MCGREGOR, D.C. (eds.): Palynology: Principles and Applications. Am. Assoc. Stratigr. Palynol. Found., 1, 29-50.

VRSALJKO, D., PAVELIĆ, D., MIKNIĆ, M., BRKIĆ, B., KOVAČIĆ, M., HEĆIMOVIĆ, I., HAJEK-TADESSE, V., AVANIĆ, R. \& KURTANJEK, N. (2006): Middle Miocene (Upper Badenian/Sarmatian) Palaeoecology and Evolution of the Environments in the Area of Medvednica Mt., (North Croatia).- Geol. Croat., 59/1, 51-63.

ZEVENBOOM, D. (1995): Dinoflagellate cysts from the Mediterranean Late Oligocene and Miocene.- Unpubl. PhD Thesis, University of Utrecht, Utrecht, $221 \mathrm{p}$.

ZONNEVELD, K.A.F., MARRET, F., VERSTEEGH, G.J.M., BOGUS, K., BONNET, S., BOUIMETARHAN, I., CROUCH, E., DE VERNAL, A., ELSHANAWANY, R., EDWARDS, L., ESPER, O., FORKE, S., GRØSFJELD, K., HENRY, M., HOLZWARTH, U., KIELT, J.F., KIM, S., LADOUCEUR, S., LEDU, D., CHEN, L., LIMOGES, A., LONDEIX, L., LU, S.H., MAHMOUD, M.S., MARINO, G., MATSOUKA, K., MATTHIESSEN, J., MILDENHAL, D.C., MUDIE, P.J., NEIL, H. L., POSPELOVA, V., QI, Y., RADI, T., RICHEROL, T., ROCHON, A., SANGIORGI, F., SOLIGNAC, S., TURON, J. L., VERLEYE, T., WANG, Y., WANG, Z. \& YOUNG, M. (2013): Atlas of modern dinoflagellate cyst distribution based on 2405 data points.- Rev. Palaeobot. Palynol., 191, 1-197. doi: 10.1016/j.revpalbo.2012.08.003

ZORN, I. (2003): Ostracoda from the Gaindorf Formation (Middle Miocene, Lower Badenian) of Mühlbach (Molasse Basin, Lower Austria).- Ann. Naturhist. Mus. Wien 104 A, 77-84.

ZORN, I. (2004): Ostracoda from the Lower Badenian (Middle Miocene) Grund Formation (Molasse Basin, Lower Austria).- Geol.Carpath, 55/2, 179-189. 
Supplement Table 1. Distribution of foraminifera in samples from the sedimentary KOS-I column.

\begin{tabular}{|c|c|c|c|c|c|c|c|c|c|c|c|}
\hline \multirow{2}{*}{ FORAMINIFERA } & \multicolumn{11}{|c|}{ KOS-I } \\
\hline & 1 & 2 & 4 & 5 & 6 & 7 & 8 & 9 & 11 & 13 & 15 \\
\hline \multicolumn{12}{|l|}{ BENTHIC } \\
\hline Amphimorphina haverina (Neugeboren) & $x$ & & $x$ & $x$ & & $x$ & & $x$ & & & \\
\hline Ammonia vienensis (d'Orbigny) & & & & & & & & & $\mathrm{x}$ & $x$ & \\
\hline Ammonia pseodobeccarii Putrja & & $x$ & & & $x$ & & & & & & \\
\hline
\end{tabular}

Anomalinoides cf. badenensis (d'Orbigny)

Asterigerinata planorbis (d'Orbigny)

Astrononion perfossum Clodius

Articulina sp.

Baggina arenaria (Karrer)

Bolivina antiqua d'Orbigny

Bolivina dilatata Reuss

Bolivina ex gr. pokorny Cicha \& Zapletalova

Bolivina moldavica Didkowski

Bolivina granensis Cicha \& Zapletalova

Bolivina fastigia Cushman

Bolivina moravica Cicha \& Zapletalova

Bolivina papulata Cushman

Bolivina pseudoplicata Heron-Allen \& Earland

Bolivina pokornyi Cicha\&Zapletalova

Bolivina sagittula Didkowski

Bolivina sarmatica Didkowski

Bolivina plicatella Cushman

Bolivina striatula Cushman

Bolivina nisporenica Didkovski

Bulimina buchiana d'Orbigny

Bulimina elongata longa d'Orbigny

Bulimina gutsulica Livental

Bulimina subulata Cushman\&Parker

Chilostomella ovoidea Reuss

Cibicidoides ungerianus (d'Orbigny)

Cursina porocostata Popescu\&Crihan

Elphidium cf. excavatum (Terquem)

Elphidium cf. subumbilicatum Czjzek

Elphidium crispum (Linne)

Elphidium ex gr. hauerinum (d'Orbigny)

Elphidium reussi Marks

Elphidium grilli Papp

Elphidium fichtelianum d'Orbigny

Elphidium perscitum Serova

Elphidium macellum tumidocamerale Bogdanowicz

$\begin{array}{ll}x & x \\ x & x\end{array}$

Elphidium incertum Williamson

Elphidium macellum (Fichtel \& Moll)

Elphidium joukovi Serova

Elphidiella vignaeuxi (Caralp\&Julius)

Elphidiella artifex (Serova)

Favulina hexagona (Williamson)

Fissurina marginata (Montagu)

Fissurina severantoni Popescu

Oolina globosa (Montagu)

$\begin{array}{cccccc}x & x & x & x & x \\ x & x & x & x & x\end{array}$

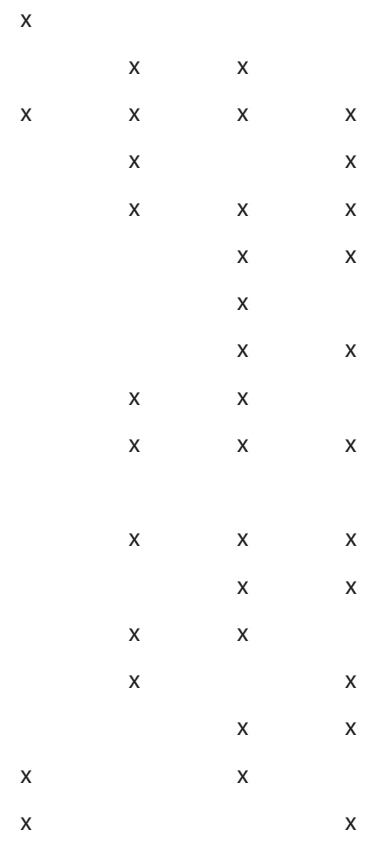

Fursenkoina sarmatica (Venglinski) 
Globobulimina pyrula (d'Orbigny)

Globulina gibba d'Orbigny

Guttulina communis d' Orbigny

Hanzawaia crassiseptata (Luczkowska)

Heterolepa dutemplei (d'Orbigny)

Laevidentalina elegans (d'Orbigny)

Lenticulina austriaca (d'Orbigny)

Lenticulina inornata (d'Orbigny)

Lenticulina calcar (Linne)

Lobatula lobatula (Walter \& Jacob)

Loxostomina digitalis (d'Orbigny)

Neugeborina longiscata (d'Orbigny)

Nonion bogdanowiczi Voloshinova

$\begin{array}{cccccc}1 & 2 & 4 & 5 & 6 & 7\end{array}$

Nonion biporus Krashenninikov

Oolina globosa (Montagu)

Palliolatella sp.

Pappina neudorfensis (Toula)

Planularia moravica (Karrer)

Porosolenia tibiscens Popescu

Porosononion martkobi (Bogdanowicz)

Pseudotriloculina consobrina (d'Orbigny)

Sigmavirgulina tortuosa (Brady)

Siphonodosaria consobrina (d'Orbigny)

Spirosigmoilinita tenuis (Czjzek)

Spirorutilus carinatus (d'Orbigny)

Uvigerina brunensis Karrer

Uvigerina pygmoides Papp \& Turnovsky

$\begin{array}{ll}x & x \\ x\end{array}$

$x$

Uvigerina semiornata d'Orbignyi

Uvigerina venusta Franzenau

Valvulineria complantata (d'Orbigny)

PLANKTONIC

Globigerina bulloides d'Orbigny

$\mathrm{X}$

Globigerina cf. subcretacea Lomnicki

Globigerina conncina Reuss

Globigerina diplostoma Reuss

Globigerina praebulloides Blow

Globigerina tarchanensis (Subbotina \& Chutzieva)

Globigerina cf. lentiana Rogl

Globigerinella regularis (d'Orbigny)

Globigerinita glutinata (Egger)

Globigerinoides apertasuturalis (Jenkins)

Globigerinoides quadrilobatus (d'Orbigny)

Globigerinoides sacculifer (Brady)

Globigerinoides trilobus (Reuss)

Globoquadrina altispira (Cushman \& Jarvis)

Globorotalia bykovae (Aisenstat)

Globorotalia cf. scitula Brady

Globoturborotalita decoraperta

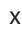

$\mathrm{x}$

$x$

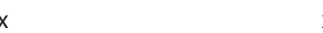

$x$

$x$

$x \quad x$

$\begin{array}{lll}x & x & x\end{array}$

$x$ 


\begin{tabular}{|c|c|c|c|c|c|c|c|c|c|c|c|}
\hline \multirow{2}{*}{ FORAMINIFERA } & \multicolumn{11}{|c|}{ KOS-I } \\
\hline & 1 & 2 & 4 & 5 & 6 & 7 & 8 & 9 & 11 & 13 & 15 \\
\hline \multicolumn{12}{|l|}{ PLANKTONIC } \\
\hline Globoturborotalita woodi (Jenkins) & $\mathrm{x}$ & $\mathrm{x}$ & & & & & & & & & $x$ \\
\hline Jenkinsella mayeri (Cusman\&Ellisor) & & & $\mathrm{x}$ & & & & & & & & \\
\hline Orbulina bilobata d'Orbigny & & & $x$ & & & & & & $x$ & & \\
\hline Orbulina suturalis Bronnimann & $x$ & & $\mathrm{x}$ & $x$ & & & & $x$ & $x$ & $\mathrm{x}$ & \\
\hline Orbulina universa d'Orbigny & $x$ & & $\mathrm{x}$ & & & $\mathrm{x}$ & & & & & \\
\hline Paragloborotalia siakensis (LeRoy) & $x$ & $\mathrm{x}$ & $x$ & & & & & & & & \\
\hline Teniutellinata pseudoedita (Subbotina) & $x$ & $\mathrm{x}$ & & & & & & & $x$ & & \\
\hline Tenuitella clemenciae (Bermudez) & $x$ & $\mathrm{x}$ & & $\mathrm{x}$ & & & & $\mathrm{x}$ & & & \\
\hline Tenuitella selleyi Li, Radford \& Banner & & $\mathrm{x}$ & $\mathrm{x}$ & & & & & $x$ & & $x$ & \\
\hline Tenuitellinata angustiumbilicata (Bolli) & & & & & & & & & $x$ & & \\
\hline Tenuitellinata juvenilis Bolli & $x$ & $x$ & & $x$ & & $x$ & & & & & \\
\hline Turborotalita quinqueloba (Natland) & $x$ & $x$ & & & & $x$ & & & $x$ & $x$ & $x$ \\
\hline Velapertina indigena Luczkowska & & & $\mathrm{x}$ & $x$ & & & & & $x$ & & \\
\hline
\end{tabular}

Supplement Table 2. Distribution of the ostracod species within the samples of the KOS-I succession.

\begin{tabular}{|c|c|c|c|c|c|c|c|c|c|}
\hline \multirow{2}{*}{ OSTRACODS } & \multicolumn{9}{|c|}{ KOS-I } \\
\hline & 1 & 2 & 4 & 5 & 7 & 8 & 11 & 13 & 15 \\
\hline Aurila cf. notata (Reuss) & $\mathrm{x}$ & & & $x$ & & & $x$ & & \\
\hline Aurila sp. & $x$ & $x$ & $x$ & $x$ & & $x$ & $x$ & $x$ & $\mathrm{x}$ \\
\hline Amnicythere sp. & & $x$ & & & & & & & \\
\hline Bosquetina carinella (Reuss) & & & & & & $\mathrm{x}$ & & & \\
\hline Butonia sp. & & & & $x$ & & & $x$ & & \\
\hline Callistocythere cf. postvallata Pietrzeniuk & & $x$ & $\mathrm{x}$ & $x$ & $x$ & $\mathrm{x}$ & $x$ & & \\
\hline Callistocythere canaliculata (Reuss) & & & & $x$ & $x$ & & $x$ & & \\
\hline Cnestocythere sp. & & $x$ & & & & & $x$ & & \\
\hline Cnestocythere truncata (Reuss) & & & $\mathrm{x}$ & & & & $x$ & & \\
\hline Costa sp. & & & & & & & & $x$ & \\
\hline Loxoconchasp. & & $x$ & $x$ & & & & & & \\
\hline Loxocorniculum cf. schmidi (Cernajsek) & & & $x$ & & & & & & \\
\hline Loxocorniculum hastatum (Reuss) & & $x$ & $x$ & & & & & & \\
\hline Olimfalunia? plicatula (Reuss) & & & & & & $x$ & & & \\
\hline Paracytheridea triquetra (Reuss) & & & & & & & $x$ & & \\
\hline Semicytherura filicata (Schneider) & & & $\mathrm{x}$ & & & & & & \\
\hline Semycytherura cf. alata (Linenklaus) & & & $x$ & $x$ & $x$ & & & & \\
\hline Tenedocythere slebrosa (Uliczny) & & & & & & & & $x$ & \\
\hline Tenedocythere sp. & $x$ & & $x$ & & & & & & \\
\hline Tenedocythere sulcatopunctata (Reuss) & & & & & & & $\mathrm{x}$ & & \\
\hline Xestoleberis glaberscens (Reuss) & $x$ & $x$ & $x$ & & & & $\mathrm{x}$ & & \\
\hline Xestoleberis sp. & $x$ & & & & & & $x$ & $x$ & $x$ \\
\hline
\end{tabular}

